\title{
Przedradziecka tożsamość narodowa w Āzji Centralnej w kontekście polityki narodowościowej ZSRR. Przegląd badań
}

Zarys treści: Artykuł ma charakter retrospektywny i odnosi się do tematyki przestrzeni społeczno-politycznej Związku Radzieckiego w Azji Centralnej ${ }^{1}$ oraz nieprzerwanie z nią związanych - religii islamu i nacjonalizmów regionalnych. Skupiając się przede wszystkim na tle historycznym regionu, treść oparta na szerokim spektrum badań prowadzi przez najważniejsze okresy kształtowania współczesnej Azji Środkowej i przywołuje najjaskrawsze przykłady radzieckiej aktywności. Poruszone w nim kwestie zarówno natury społecznej, jak też prawno-administracyjnej nabierają szczególnego znaczenia w obliczu obecnej geopolitycznej aktywności Moskwy w strefie tzw. żywotnych interesów. W tym wymiarze, treść artykułu nasuwa na myśl paralelę

$1 \mathrm{Na}$ potrzeby niniejszego artykułu termin „Azja Centralna”, stosowany w piśmiennictwie światowym, używany jest zamiennie z terminem „Azja Środkowa”, stosowanym w polskim piśmiennictwie historycznym. Samo pojęcie „Azja Centralna” jest terminem nowym i w swoim obecnym geopolitycznym znaczeniu odnosi się do południowych terenów ZSRR, których rdzeń stanowią niepodległe republiki - Kazachstanu, Uzbekistanu, Kirgistanu, Turkmenistanu i Tadżykistanu. Region obejmuje słabo zaludniony obszar śródlądowy zamknięty szczelnie granicami, które określone są: na zachodzie bogatym w ropę akwenem Morza Kaspijskiego, na północy - bezkresnymi połaciami zimnej Syberii, na wschodzie - gospodarką chińskiego „Smoka”, a na południu - atomowym Iranem i wiecznie niespokojnym Afganistanem. Jeszcze w czasach radzieckich Turkmenistan, Tadżykistan, Kirgistan, Uzbekistan i południową część Kazachstanu mianowano Azją Środkową. Niemniej jednak, wraz z uzyskaną niepodległością, republiki azjatyckie postanowiły o zmianie dotychczasowej terminologii. I tak, w 1993 r. na spotkaniu przywódców regionu w Aszchabadzie podjęta została w tej materii decyzja. Stosowaną od 1924 r. Azję Środkową i Kazachstan zastąpiono jednym terminem - Azja Centralna. Najważniejszą przesłanką stojącą za tą decyzją była chęć zdystansowania się od Rosji i tym samym wydzielenia nowego subregionu w przestrzeni poradzieckiej. Wszystko zgodnie z założeniami teorii postkolonialnej.

Załęski P., Kultura polityczna więzi w Azji Centralnej, Oficyna Wydawnicza ASPRA-JR, Warszawa 2011, s. 17; Wierzbicki A., Etnopolityka w Azji Centralnej, Dom Wydawniczy Elipsa, Warszawa 2008, s. 25; Falkowski M., Charakterystyka regionu Azji Centralnej, [w:] B. Bojarczyk, A. Ziętek [red.], Region Azji Centralnej jako obszar wpływów międzynarodowych, Wydawnictwo Uniwersytetu Marii Curie-Skłodowskiej, Lublin 2008, s. 29. 
miedzy polityką zagraniczną Federacji Rosyjskiej i jej instrumentami a polityką wewnętrzną Związku Radzieckiego, w której ta pierwsza jest głęboko zakorzeniona.

Outline of content: This article is retrospective in nature and covers the subject of social and political influence of the Soviet Union in Central Asia, as well as several factors strictly associated with this region, e.g. the religion of Islam and regional nationalisms. Based on a broad spectrum of research with primary focus on the region's historical background, the content covers the key periods of development of modern Central Asia and evokes the most evident examples of Soviet activity in the area. The social issues, as well as legal and administrative matters addressed in the article acquire new importance in connection with Moscow's current geopolitical activity in terms of its vested interests. From this point of view, this article depicts the parallel between the Russian Federation's foreign policies and its instruments, and the internal policy of the Soviet Union, in which the former is deeply rooted.

Słowa kluczowe: polityka narodowościowa, nacjonalizm, islam, ZSRR, delimitacja, Azja Centralna

Keywords: national policy, nationalism, Islam, delimitation, USSR, Central Asia

\section{Przedradziecka tożsamość narodowa Azji Centralnej}

Państwa Azji Centralnej znajdują się w samym sercu Eurazji. Obszar ten od wieków pozostawał pod wpływem wielkich religii i kultur; istniał na skrzyżowaniu cywilizacji; graniczył bądź stanowił peryferia wielkich imperiów. Jego rozległe tereny dzieliły między sobą ludy koczownicze i osiadłe. Przechodzący przez serce Azji Centralnej Jedwabny Szlak był miejscem spotkań międzynarodowych handlarzy i kupców. Wiele narodowości migrowało i osiedlało się w regionie. Wielkie cesarstwa, imperia i chanaty podbijały i rządziły rozległymi terenami Azji Centralnej. Każde z tych wydarzeń miało zróżnicowany, ale wyraźny wpływ na kulturę i politykę Azji Środkowej z wartościami zorientowanymi na południe, aniżeli północ Globu.

Od czasu mongolskich najazdów na Azję Centralną do radzieckich podbojów zmiana polityczna w regionie najczęściej wprowadzana była przy użyciu przemocy. Brutalnie implementowane zmiany usprawiedliwiano religią, narodowością, a niekiedy zwykłą chęcią podboju. Starcia o charakterze społecznym i kulturowym, do których dochodziło na przestrzeni wieków, doprowadziły do niezwykle skomplikowanej sytuacji między obecnie występującymi w Azji Środkowej grupami etnicznymi².

\section{Podbój Azji Centralnej przez Rosję}

W 1885 r. Imperium Rosyjskie zajęło całą Azję Centralną ${ }^{3}$. Ekspansja terytorialna rozpoczęła się w połowie XIX w. i zakończyła aneksją obszaru, którego bezkresne terytorium rozciągało się od Morza Kaspijskiego do Chin, Syberii na wschodzie,

2 Batalden S. K., Batalden S. L., The Newly Independent States of Eurasia: Handbook of Former Soviet Republics, The Oryx Press, Phoenix 1997, s. 178.

3 W 1895 roku na mocy porozumienia brytyjsko-rosyjskiego Rosji została przyznana większa część Pamiru. Ibidem. 
aż po Indie i Persję na krańcach południowych ${ }^{4}$. Obszar zdominowany był przez ludy tureckie. Wyjątek stanowili Tadżycy, postrzegani jako lud indoeuropejski, oraz ludy Pamiru. Północną część regionu zamieszkiwali koczownicy, południową zaś ludność osiadła, najczęściej w oazach. Dzieła kolonizacji regionu dopełnili bolszewicy, niszcząc lokalną religię, infrastrukturę, zasoby, tradycję bogatej historii Azji Centralnej. Największe piętno na lokalnej społeczności odcisnęła władza, polityka i dominacja radziecka w XX wieku.

Północne obszary Azji Centralnej, na które składały się rozległe stepy zamieszkiwane przez ludy pasterskie, były stopniowo podbijane przez Rosjan w XVII, XVIII i XIX wieku. Pierwsze kontakty Rosji z Azją Środkową datuje się na XVI w., kiedy Moskwa zaczęła wysyłać swoje poselstwa do tamtejszych chanatów w celu nawiązania stosunków gospodarczych, których głównym przedmiotem miały być uprawy bawełny i hodowle jedwabników. W kolejnych stuleciach w zdobywaniu ziem Azji Centralnej coraz większe znaczenie odgrywała sytuacja geopolityczna w regionie oraz tzw. misja kulturowa, czyli przekonanie o potrzebie cywilizowania prymitywnych ludów i zaprowadzeniu między nimi trwałego pokoju, co w przyszłości miało przełożyć się na większe bezpieczeństwo na szlakach handlowych przecinających region. W pierwszej połowie XVIII w. nastąpiły pierwsze zdobycze terytorialne. Początkowo w skład Rosji weszły tereny obecnego północno-zachodniego Kazachstanu (należały one ówcześnie do tzw. Małego Żuzu'), graniczące z Chanatem Chiwy. W 1740 r. rozciągnięto protektorat nad ziemiami Średniego Żuzu, przylegającymi do terytorium Buchary. Na początku XIX w. przyłączone zostały ziemie Starszego Żuzu. Obecnie są to tereny południowo-wschodniego Kazachstanu, ówcześnie peryferie Chanatu Kokandu. Działania zmierzające do przekształcenia obszarów zajmowanych przez Kazachów w kolonię obejmowały aktywność prowadzoną na trzech płaszczyznach: militarnej (sprowadzanie wojsk kozackich), ekonomicznej (przejmowanie ziem kazachskich, wprowadzenie podatków) oraz politycznej (zmiany administracyjne ograniczające prawa Kazachów). Początkowo skolonizowane obszary Azji Środkowej wcielono w granice trzech generalnych gubernatorstw - orenburskiego, zachodnio-syberyjskiego i turkiestańskiego, a następnie dwóch - stepowego i turkiestańskiego. Po wieloletnich działaniach, podporządkowując plemiona turkmeńskie i przezwyciężając mieszkańców Pamiru, cel kolonizacji Azji Centralnej został zrealizowany. Imperium Rosyjskie zaangażowało się w rywalizację geopolityczną z Wielką Brytanią, w tzw. Wielką Grę . Zarządzanie nowym terytorium odbywało się na podstawie rozporządzeń wydawanych przez cara Aleksandra II. Podział terytorialny przeprowadzany był bez brania pod uwagę czynnika plemiennego czy etnicznego, a powstałe okręgi administrowane były przez rosyjskich naczelników.

4 Obszar ten ówcześnie nazywano Turkiestanem Zachodnim; Wschodni z kolei stanowił część Chin.

5 Edwards M., A Broken Empire: Kazakhstan, „National Geographic Magazine”, 183, No. 3, March 1993, s. 29.

6 Jedna $\mathrm{z}$ trzech kazachskich ord.

7 Więcej: Hopkirk P., The Great Game: The Struggle for Empire in Central Asia, New York; Tokyo \& London: Kodansha International 1994. 
Ludność rdzenna nie miała dostępu do władzy na okupowanych terenach. Rozległe tereny Azji Środkowej eksploatowano i to nie tylko pod kątem ziemskim czy surowcowym, ale również politycznym. W $1886 \mathrm{r}$. na mocy reformy z lat 1867-1868 Imperium Rosyjskie przejęło ziemie w całej Azji Centralnej. Istotnym elementem tych zmian były działania agrarne i demograficzne. Niezwykle ważna była również polityka przesiedleńcza, która doprowadziła do wywłaszczenia ludności rdzennej ${ }^{8}$.

W drugiej połowie XIX w. Rosja podejmowała działania, które miały przybliżyć ją do zajęcia również południowych terenów Azji ${ }^{9}$. Nie bez znaczenia pozostawały aspiracje rosyjskiej władzy w próbach uzyskania dostępu do Oceanu Indyjskiego i powstrzymania ekspansji Wielkiej Brytanii w walce o wpływy w Azji Środkowej ${ }^{10}$. Zdobycie całkowitej kontroli nad Azją Centralną było wypracowanym z Imperium Brytyjskim konsensusem równoważącym dążenia Moskwy do uzyskania dostępu do Oceanu Indyjskiego z próbą zachowania zwierzchnictwa brytyjskiego nad Indiami ${ }^{11}$.

Mapa 1. Azja Centralna około 1815 roku

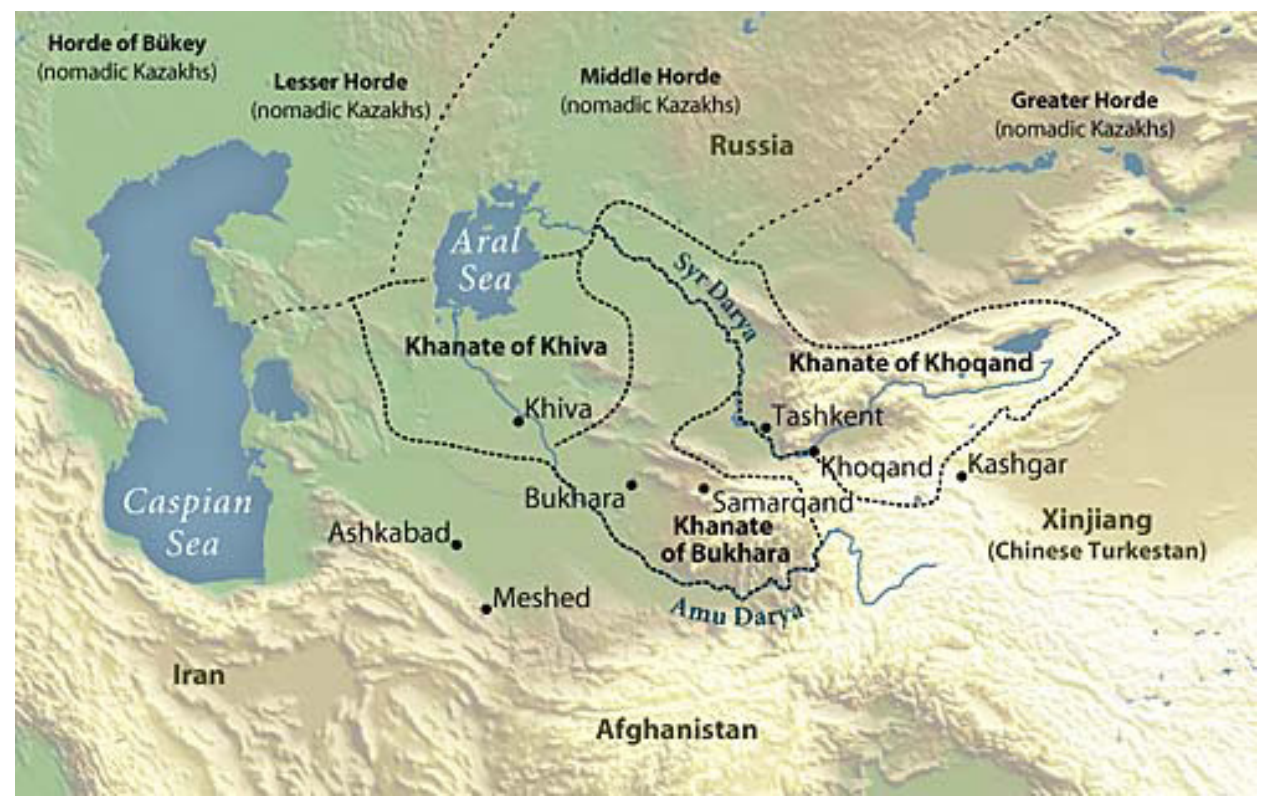

Źródło: Metropolitan Museum of Art, strona internetowa https://www.metmuseum.org/toah/ ht/10/nc/map_19th.htm stan z dnia 23-06-2014.

8 Bodio T., Załęski P., Elity władzy w Azji Centralnej. Tradycja - Modernizacja - Etnopolityka, Dom Wydawniczy ELIPSA, Warszawa 2008, s. 92-100.

9 Południowe tereny miały długą historię osadnictwa miejskiego.

10 Tu: głównie na terenie obecnych Iranu, Afganistanu i Pakistanu, a także Tybetu.

11 Abazov R., Culture and Customs of the Central Asian Republics, Greenwood 2007, s. 35. 
Bezpośrednio przed podbiciem południowych terenów Azji Centralnej obszar ten znajdował się pod kontrolą trzech jednostek politycznych - Emiratu Buchary, Chanatu Chiwy i Chanatu Kokandu. Całkowicie im podporządkowane były ludy osiadłe. W mniejszym stopniu zależności pozostawały znajdujące się na ich terytorium plemiona koczownicze. Wędrowne plemiona $\mathrm{z}$ północy regionu zdołały zachować całkowitą suwerenność. Wraz z ustanowieniem rosyjskiego gubernatorstwa - Turkiestanu, emirat i chanat $\mathrm{z}$ Chiwy zachowały pewien poziom neutralności, znajdując się pod protektoratem Rosji. Z kolei Chanat Kokandu po kilku latach lennictwa upadł i został wcielony w granice Turkiestanu w 1876 roku. W tamtym okresie Kokand zamieszkiwany był przede wszystkim przez Sartów, którzy dominowali i sprawowali kontrolę nad południowymi terenami obecnego Kirgistanu. Wiele ówczesnych plemion kirgiskich zostało obalonych i wcielonych do carskiej Rosji. Od początku obecności Rosjan w Azji Środkowej implementowane tam zmiany i reformy miały prowadzić do osłabienia tradycyjnych więzi plemiennych i rodowych ${ }^{12}$.

Arena polityczna Azji Centralnej początku XX w. była naznaczona działaniami ruchu dżadydów, którzy znani byli ze swojej antykolonialnej postawy i przekonań nacjonalistycznych ${ }^{13}$. Przedstawiciele tego ruchu szybko znaleźli poparcie wśród bolszewików, którzy szukali sojuszników w walce z Imperium Rosyjskim. Jednak wzajemne korzyści nie były wystarczające, by między nimi zawiązała się długotrwała współpraca rozwiązująca nurtujące społeczność środkowoazjatycką problemy. Proporcjonalnie do wzrostu znaczenia bolszewików w regionie nabierał siły opór lokalnej społeczności przed kolejną formą kolonizacji. Po rewolucji bolszewickiej rozwinęły się w ZSRR polityki narodowe mające odzwierciedlenie w zmianach terytorialnych, których echa do dzisiaj rozbrzmiewają nad Azją Centralną ${ }^{14}$. Radziecka władza starała się zabezpieczyć swoją pozycję w regionie, podejmując działania mające również na celu izolację regionu, odcinając wielowiekowe więzi łączące ludy środkowoazjatyckie z najbliższymi sąsiadami - Iranem, Chinami i Afganistanem ${ }^{15}$.

Powstanie ZSRR miało być jednoznaczne $\mathrm{z}$ radykalnym oderwaniem się od carskiej orientacji ideologicznej oraz formy i trybu panujących w Imperium relacji

12 Sartami nazywano populację Azji Centralnej o osiadłym trybie życia, w skład której wchodzili przedstawiciele ludów tureckich i irańskich; byli to przodkowie współczesnych Uzbeków i Tadżyków. Bohr A., Crisp S., Kyrgyzstan and the Kyrgyz, [w:] G. Smith [red.], The Nationalities Question in the Post-Soviet States, Longman, London \& New York 1996, s. 404.

13 Inaczej dżadydyzm to muzułmański (tatarski) ruch religijno-społeczny powstały pod wpływem zachodnich idei i prądów naukowych w 1883 roku. Występował w Turkiestanie i Tatarstanie. Nazwa pochodzi od tureckich słów oznaczających nową metodę. Ruch ten popularny był wśród muzułmanów rosyjskich, zwłaszcza wśród Tatarów, będąc jednym z reformatorskich, antykolonialnych ruchów, które pojawiły się w XIX-wiecznym świecie muzułmańskim, i których celem było pogodzenie zachodniej nowoczesności z kulturą islamską.

14 Khalid A., The Politics of Muslim Cultural Reform: Jadidism in Central Asia, University of California Press, Berkeley 1998, s. 285-286.

15 Shaw C., Friendship under Lock and Key: the Soviet Central Asian Border, 1918-1934, „Central Asia Survey", Vol. 30, No. 3-4, 2011, s. 331-348 (344). 
etnicznych i religijnych. Przywileje wszystkich republik związkowych były prawnie uznawane i wcielone w zapisy Konstytucji ZSRR ${ }^{16}$ oraz poszczególnych narodowych systemów prawnych. Polityka Partii Komunistycznej skupiona była na zniesieniu różnic społeczno-ekonomicznych występujących na płaszczyźnie państw związkowych i ich obywateli, promując i działając na rzecz gospodarczego, społecznego i kulturowego rozwoju ZSRR. Wzmacniano zatem narody Azji Centralnej w drodze indygenizacji, a za cel nadrzędny władzy radzieckiej postawiono zespolenie różnych grup etnicznych w jeden, spójny naród radziecki ${ }^{17}$. Początkowo promowano także odejście od carskiej polityki asymilacji i rozwój lokalnych języków i kultur. Za tak liberalną działalnością krył się jednak długoterminowy cel zmarginalizowania regionalnie występujących dążeń niepodległościowych poprzez przyznanie lokalnym narodowościom imitacji statusu państwowego, który z czasem miał uwypuklić nierówności społeczne ${ }^{18}$.

Początkowo Rosjanie nie ingerowali w życie lokalnych wspólnot Azji Centralnej, choć z czasem sytuacja uległa zmianie. Na przełomie wieków XIX i XX w regionie zaczęło się osiedlać coraz więcej ludności słowiańskiej i kozackiej. Zmieniająca się równowaga demograficzna oraz postępujące wywłaszczenia ziemi lokalnych nomadów doprowadziły w 1916 r. do powstania, które w szybkim czasie objęło cały Turkiestan. Krwawe stłumienie zamieszek doprowadziło do masowej ucieczki Kirgizów i Kazachów w kierunku Chin, co w konsekwencji przełożyło się na dalsze postępujące dysproporcje w składzie etnicznym regionu ${ }^{19}$.

Mimo bogatej historii Azji Centralnej, trudno mówić o jakiejkolwiek tożsamości narodowej regionu z okresu przed kolonizacją radziecką. Do tego czasu obszar Azji Środkowej pozostawał bezkresnym stepem, który nieustannie przemierzały niezliczone karawany, a koczownicy podlegali rządom chanatów i władzy klanów ${ }^{20}$. Tożsamość grupowa powstawała w wyniku wymieszania się wielu niepaństwowych cech i wartości. Większe znaczenie miało pochodzenie z konkretnego miasta bądź regionu czy członkostwo w lokalnej społeczności ${ }^{21}$. Równie często identyfikowano

16 Rozdziały 6. i 7. Konstytucji ZSRR z 1936 r., Bucknell University, strona internetowa http:// www.departments.bucknell.edu/russian/const/1936toc.html stan z dnia 23-06-2014.

17 Narodowość stanowi wartość dynamiczną, która może ulec zmianie w wyniku oddziaływania na nią czynnika kulturowego. Hirsch F., Empire of Nations: Ethnographic Knowledge and the Making of the Soviet Union, Cornell University Press, New York 2005, s. 119.

18 Bremmer I., Reassessing Soviet Nationalities Theory, [w:] I. Bremmer, R. Taras [red.], Nations and Politics in the Soviet Successor States, Cambridge University Press, Cambridge 1993, s. 9.

19 D'Encausse H. C., Organizing and Colonizing the Conquered Territories, [w:] E. Allworth [red.], Soviet Nationality Problems, New York: Columbia 1971, s. 211; Kolstoe P., Russians in the Former Soviet Republics, Hurst, London 1995, s. 23-24; Pipes R., The Formation of the Soviet Union: Communism and Nationalism 1917-1923, Massachusetts: Harvard Cambridge 1970, s. 82; Dienes L., Pasturalism in Turkestan: Its Decline and Its Persistence, „Soviet Studies”, 27 (1975), s. 343-365 (tu: 350).

20 Denison M., Identity Politics in Central Asia, „Asian Affairs”, 34 (1), 2003, s. 58.

21 Przykładem są Uzbekistan i Kirgistan. Segars A., Nation Building in Turkey and Uzbekistan, [w:] T. Evereath-Heath [red.], Central Asia, Aspects of Transition, London New York, Routledge Curzon 2003, s. 91. 
się przez pryzmat religii muzułmańskiej ${ }^{22}$. W najwyższym stopniu tożsamość definiował prowadzony tryb życia - koczowniczy i pasterski - aniżeli wspominane wcześniej język czy pochodzenie etniczne ${ }^{23}$.

Na początku XX w. opresje carskie wykorzystał w swoich dążeniach do władzy Lenin, określając Imperium Rosyjskie „więzieniem narodów”. Jeszcze przed samą rewolucją bolszewicką Lenin wyobrażał sobie Związek Radziecki jako państwo składające się $\mathrm{z}$ autonomicznych regionów wyodrębnionych na podstawie podziału administracyjno-politycznego, aniżeli etnicznego. Ale zanim zdecydował się na konkretne kroki, przeprowadził wiele dyskusji nt. realizacji procesu samookreślenia narodów Azji Centralnej. W końcu na ósmym Kongresie Partii Komunistycznej wspólnie ze Stalinem zdecydowali się wprowadzić politykę skoncentrowaną na dezintegracji panującego $\mathrm{w}$ regionie nacjonalizmu poprzez udzielenie zamieszkałym tam grupom etnicznym form statusu państwowego ${ }^{24}$.

Od początku, czyli mniej więcej od daty powstania radzieckiej etno-terytorialnej federacji, Lenin poważnie traktował również kwestię narodowości ${ }^{25}$. Niemniej jednak nieprzerwanie dziwiła go i napawała obawą siła mobilizacyjna utożsamianego z procesami narodowymi nacjonalizmu, której doświadczył w trakcie rewolucji i wojny domowej ${ }^{26}$. Można również zaryzykować stwierdzenie, iż późniejsza radykalna strategia narodowa wyrastała z tego właśnie doświadczenia przedrewolucyjnej aktywizacji ruchów nacjonalistycznych. W późniejszym czasie postawę Lenina zaczął wspierać Stalin. Dokonując pewnego rozdzielenia między nacjonalizmem państwa zaborcy a nacjonalizmem narodów uciskanych, razem dążyli do zmiany wizerunku Rosjan wśród nierosyjskiej populacji Związku.

Ludność nierosyjska nie znała w tamtym czasie rozdziału proletariatu od mieszczaństwa, co w oczach władzy poważnie osłabiało jej siłę rewolucyjną. W miejscu brakujących klas społecznych postanowiono więc rozwinąć i zinstytucjonalizować narodowości, przydzielając im jednocześnie pewien stopień autonomii terytorialnej ${ }^{27}$. Tam, gdzie było to możliwe, bolszewicy współpracowali z lokalnymi elitami, a gdzie

22 Haugen A., The Establishment of National Republics in Soviet Central Asia, New Hampshire: Palgrave MacMillan, 2003, s. 35.

23 Lewis M. L., Ethnic Strife and the Reinvention of Uzbek Identity, GeoCurrents.info, strona internetowa

http://geocurrents.info/geopolitics/ethnic-strife-and-the-reinvention-of-uzbek-identity, stan z dnia 23-06-2014; Fedorenko V., Central Asia: From Ethnic to Civic Nationalism, „Rethink Paper”, March 2012, s. 6.

24 Martin T., The Affirmative Action Empire: Nations and Nationalism in the Soviet Union, 1923-1939, Cornell University Press, Ithaca 2001, s. 3.

25 Hirsch F., op. cit., s. 65-69.

26 Martin T., An Affirmative Action Empire: The Soviet Union as the Highest Form of Imperialism, [w:] R. G. Suny, T. Martin [red.], A State of Nations: Empire and Nation-Making in the Age of Lenin and Stalin, New York 2001, s. 68.

27 Slezkine Y., USSR as a Communal Apartment, or How a Socialist State Promoted Ethnic Particularism, „Slavic Review”, Vol. 53, No. 2, Summer 1994, s. 421. 
ich brakowało - z przedstawicielami lokalnych grup narodowych ${ }^{28}$. Ze względu na fakt, iż w tamtym czasie nie było mowy o jakiejkolwiek polityce narodowościowej, władza radziecka odwoływała się do działań z zakresu pomocy finansowej i promocji instytucjonalizacji narodowości w poszczególnych zakątkach państwa radzieckiego ${ }^{29}$.

Sam proces regionalizacji Związku Radzieckiego opierał się nie tylko na przesłance narodowej, ale w dużym stopniu polegał też na względach ekonomicznych. Co więcej, z podziałem Związku na jeszcze mniejsze jednostki administracyjne łączono nadzieję na przyspieszoną regenerację gospodarczą kraju po wojnach - światowej i domowej. Badając ówczesną Rosję, Francine Hirsch stwierdziła, iż w tamtym czasie ZSRR przyjął znany obecnie wszystkim kształt tylko dlatego, że rządząca Partia Komunistyczna nie była w stanie w pełni kontrolować ani wypracować jednolitego podejścia do procesu regionalizacji. W efekcie podział państwa był serią eksperymentów, w trakcie której wszystko odbywało się na zasadzie prób i błędów ${ }^{30}$. Sytuacja była na tyle niestabilna organizacyjnie i prawnie, że nawet konstytucja z 1924 r. nie była w stanie w pełni zdefiniować statusu wchodzących w skład ZSRR terytoriów narodowych. W tamtym czasie struktura państwowa nieprzerwanie ewoluowała. Wpływ na nią miała nie tylko doktryna komunistyczna, ale przede wszystkim warunki panujące na obrzeżach imperium, gdzie oddziaływanie bolszewików było słabe, a przestrzeń narodową tworzyły więzi kulturowo-religijne oraz historyczna rywalizacja etniczna ${ }^{31}$.

Zapisane w Deklaracji Praw Ludu Pracujacego i Wyzyskiwanego z 1918 r. prawo do autonomii narodowej przysparzało więcej problemów aniżeli korzyści. Przede wszystkim na poziomie stosowanych taktyk w procesie rozstrzygania, które społeczności należy uznać za naród; którym przyznać terytorium i jak je wykorzystać, by osiągnąć maksimum korzyści politycznych ${ }^{32}$. W teorii autonomia miała przyznawać władzę nierosyjskim mniejszościom narodowym, których aktywność lokalna miała w przyszłości służyć realizacji celów komunistycznych. W praktyce wyłaniające się elity polityczne, a przede wszystkim tło społeczno-kulturowe, z którego się wywodziły, nie wpisywały się w strategię organizacyjną bolszewików, a nawet stanowiły zagrożenie ich władzy. Nie chcąc zatem oddawać władzy lokalnym nacjonalistom, postanowiono wspierać procesy tworzące narodowe elity komunistyczne ${ }^{33}$.

Jednocześnie podejmowano wszelkie kroki mające na celu promocję tożsamości i świadomości narodowej wśród nierosyjskiej społeczności. Improwizowane przez bolszewików rozwiązania kwestii narodowej odbywały się w trzech etapach czasowych. W pierwszym, bolszewicy próbowali sprostać oczekiwaniom lokalnych narodowości,

28 Hirsch F., op. cit., s. 65-69.

29 Martin T., An Affirmative Action Empire: The Soviet Union as the Highest Form of Imperialism, s. 67.

30 Hirsch F., op. cit., s. 65.

31 Smith J., The Bolsheviks and the National Question, 1917-23, Palgrave Macmillan, London 1999, s. 30.

32 Schafer D. E., Local Politics and the Birth of the Republic of Bashkortostan, 1919-1920, [w:] R. G. Suny, T. Martin [red.], op. cit., s. 166.

33 Smith J., The Bolsheviks and the National Question, s. 93-94. 
przyznając im prawo rządzenia populacją nierosyjską, a kiedy to okazało się niewystarczające, wprowadzono politykę autonomii narodowej. W ostatnim etapie zdecydowano się na realizację tzw. akcji afirmatywnej ${ }^{34}$. Połączenie tej strategii z delimitacją granic wpłynęło na postrzeganie pewnych konkretnych narodowości jako formy prawnej nabywania przywilejów narodowych. Na początku lat 30. wszyscy już posługiwali się kategoriami narodowymi, w tym ludność koczownicza i rolnicza, której dotychczas instytucjonalizacja nie interesowała. „Wpisywano” się w narodowości, które były najmocniej uprzywilejowane, stosowano ich język w celu nabycia praw gospodarczych, administracyjnych i politycznych. Konsekwencją tamtych decyzji była narodowość, która wyewoluowała do poziomu podstawowego wyznacznika tożsamości obywatelskiej ${ }^{35}$.

Delimitacja ZSRR była o tyle istotna, że to od niej tak naprawdę zaczęto w pełni realizować radziecką politykę narodowościową. Wszystko odbyło się w oparciu o dwa przenikające się procesy. Pierwszy z korzeniami w wojnie domowej, skupiony na ideach narodowościowych, odnosił się do obietnicy samookreślenia narodów, którego efekty miały wspomóc siły rewolucji. Drugi wyrosły na tle odbudowy ekonomicznej państwa po wojnie światowej był urzeczywistnieniem regionalizacji zapoczątkowanej kilka lat wcześniej w celu stworzenia jednostek gospodarczych efektywnie realizujących założenia gospodarki centralnie planowanej ${ }^{36}$.

„Sowiecki eksperyment”37 trwał do roku 1991.

\section{Multietniczna przestrzeń azjatycka}

Rozkład mniejszości etnicznych w Azji Centralnej38 jest szczególny ze względu na rozsianych po całym regionie przedstawicieli poszczególnych wspólnot narodowych. Na przełomie wieków rdzenne grupy etniczne nieustannie się przemieszczały i integrowały ze sobą. Dopiero w XV w. zaczęły formować się koczownicze plemiona Kazachów, Uzbeków, Kirgizów i Turkmenów. Najdłuższa w regionie jest historia Tadżyków, której początki sięgają X wieku³. Obecnie nie wszystkie grupy etniczne zamieszkują rodzime obszary bezkresnych ziem Azji Centralnej. Wiele z tych grup miesza się ze sobą, np. w Kotlinie Fergańskiej. Co też w dużym stopniu jest efektem wielokrotnie zmienianych przez władze radzieckie granic $\mathrm{w}$ regionie ${ }^{40}$.

34 Martin T., The Affirmative Action Empire: Nations and Nationalism in the Soviet Union, 1923-1939, s. 13.

35 Hirsch F., op. cit., s. 145.

36 Martin T., The Affirmative Action Empire: Nations and Nationalism in the Soviet Union, 1923-1939, s. 31-34.

37 Suny R. G., Ambiguous Categories: Stats, Empires and Nation, „Post Soviet Affairs”, 11 (2), 1995, s. 192.

38 Więcej: Rohoziński J., Bawetna, Samowary i Sartowie. Muzułmańskie Okrainy Carskiej Rosji 1795-1916, Wydawnictwo Akademickie Dialog, Warszawa 2014 (przede wszystkim: s. 48-69, 604-646).

39 Tadżyków uważa się za rdzennych mieszkańców Azji Centralnej; przedstawiciele tej narodowości stworzyli najdawniejszą cywilizację i pierwsze ośrodki miejskie w regionie.

40 Zongqi Z., Ethnic and Religious Contradictions and Their Impacts in Central Asia, [w:] Xintian Yu [red.], Cultural Impact on International Relations, The Council For Research in Values and Philosophy, Washington, Cultural Heritage and Contemporary Change Series III, Asia, Vol. 20, 2002, s. 184. 
Zawiłości tożsamości etnicznej ludów Azji Środkowej wynikają z wielowiekowej historii wzajemnych relacji. Tysiąc lat temu rolnicy i mieszkańcy osad miejskich ulokowanych na zachód od górskich pasm Pamiru i Tien Szanu porozumiewali się językami z rodziny irańskiej, blisko związanymi z językiem perskim. Aczkolwiek to pasterze z ludów koczowniczych, posługujący się odmianami języka tureckiego, zaczęli dominować w regionie pod względami politycznymi i militarnymi, a w konsekwencji również językowymi. Niemniej jednak, w niektórych ośrodkach miejskich w zachodniej i południowej części Azji Centralnej, m.in. w Samarkandzie, wśród mieszkańców nieprzerwanie dominował język perski. Na terenach północnych zachowały się języki z rodziny zachodnio-tureckich, włączając w to język kazachski oraz tzw. staro-uzbecki. Na początku XVI w. koczownicze plemiona uzbeckie zaczęły zdobywać coraz większą kontrolę nad tym terytorium. W tym samym czasie wyżyny Tien Szan zamieszkiwała, odizolowana od reszty populacji Azji Środkowej i zajęta sezonowym wypasem bydła, ludność posługująca się zachodnio-turecką grupą języków, Kirgizi ${ }^{41}$.

Przed rosyjską kolonizacją Azja Centralna była regionem o lenniczym statusie. Dla jej mieszkańców większą wartość stanowiły więzi geograficzne, ekonomiczne, a nawet językowe, aniżeli etniczne. Między plemionami dochodziło do walk, często prowadzących do wzajemnego wyniszczenia. Notowano również przypadki kooperacji przy rozwiązywaniu wspólnych dla regionu problemów ${ }^{42}$. XIX-wieczni podróżnicy i etnografowie dzielili ludność Azji Centralnej klasyfikując ich jako Kazachów, Kirgizów, Turkmenów, Tadżyków, Uzbeków, Sartów, Turków oraz Karakałpaków. Kazachowie, Kirgizi i Turkmeni tworzyli konfederacje klanowe na podstawie więzi, z którą się utożsamiali i jaka łączyła ich z mitycznymi przodkami ${ }^{43}$.

Przywiązanie do historycznego dziedzictwa integrowało członków turkmeńskich grup. Na każdą z nich składał się szereg mniejszych liczebnie plemion będących sumą jeszcze mniejszych komórek rodzinnych. W tamtym czasie klany, plemiona były podstawową polityczną jednostką organizacyjną, które nierzadko walczyły ze sobą o władzę. A. L. Edgar określał je mianem „głównego źródła solidarności i wzajemnego wsparcia" ${ }^{4}$. Z kolei Kazachowie podzieleni byli na trzy ordy, zwane żużami - Wielką, Małą i Średnią, które tworzyły mniejsze grupy plemienne ${ }^{45}$.

Wśród ludności osiadłej nomenklatura społeczna była bardziej złożona. Rosjanie nazywali tę ludność Sartami ${ }^{46}$. Część etnografów zakładało, że Sart stanowi kategorię

41 Lewis M. L., op. cit.

42 Tabyshalieva A., The Challenge of Regional Cooperation in Central Asia. Preventing Ethnic Conflict in Ferghana Valley, „Peaceworks”, No. 28, United States Institute of Peace 1999, s. 3.

43 Khalid A., op. cit., s. 188.

44 Edgar A. L., The Making of Soviet Turkmenistan, Princeton University Press, Princeton 2004, s. 21.

45 Brill Olcott M., The Kazakhs, Hoover Institution Press, Stanford 1987, s. 9-16.

46 Niektórzy badacze mianem Sartów określają grupę osiadłej, przeważnie miejskiej ludności tureckojęzycznej, która zatraciła przynależność rodowo-plemienną. Inni: Uzbeków i Tadżyków wspólnie zamieszkujących południowe tereny Uzbekistanu w czasach przedrewolucyjnych. [więcej Bodio T., Załęski P., op. cit.]. 
etniczno-rasową. Tym samym próbując dopełnić obraz przedstawiciela tej grupy, starali się nakreślić jego cechy językowe i rys fizyczny. Najczęstszym i najbardziej popularnym podziałem Sartów był rozdział na Tadżyków i Uzbeków bądź Tadżyków i Turków. Co w pewnym stopniu oparte było na wspomnianych powyżej kategoriach - Tadżyków posługujących się językiem perskim lub będących pochodzenia perskiego oraz Uzbeków porozumiewających się językiem z rodziny tureckiej lub będących tureckiego pochodzenia. Tego typu rozdzielenie powodowało jednak spore trudności w procesie oszacowania demograficznego regionu, albowiem kategorie lingwistyczne obu języków przenikały się i uzupełniały, czyniąc je bardzo podobnymi. Co więcej, znaczna część społeczeństwa była dwujęzyczna, z językiem perskim dominującym wśród wyedukowanej ludności obszarów miejskich ${ }^{47}$.

W latach 20. XX w. zaczęto stosować ujednolicone nazewnictwo w stosunku do ludów tureckojęzycznych, określając ich Uzbekami. Niestety, nowa kategoria etniczna przekształciła przestrzeń społeczną ówczesnej Azji Centralnej. Ludność posługującą się językiem perskim (tadżyckim) i tureckim z naleciałościami perskimi, określaną dotychczas jako Sartowie, podzielono, a ich przedstawicieli przypisano do różnych grup etnicznych. Często pozostawiając ich w enklawach etnicznych na terytorium innego państwa ${ }^{48}$. Biorąc pod uwagę procesy narodowe, Uzbekistan stanowi wyjątek na tle pozostałych republik radzieckich. Budowa narodu w Uzbekistanie opierała się na przynależności terytorialnej poszczególnych grup etnicznych, aniżeli przynależności językowej. Niemniej jednak obywateli republiki charakteryzowała wielojęzykowość. Naród uzbecki powstał z dwóch grup ludzi. Pierwsza z nich, posługująca się językami perskimi, zamieszkiwała obszary Buchary, Samarkandy i innych mniejszych ośrodków miejskich ulokowanych w dorzeczach Amu Darii i Syr Darii. Druga grupa zamieszkiwała północne tereny kraju i komunikowała się za pomocą języków tureckich ${ }^{49}$. Obecni mieszkańcy Uzbekistanu to ich potomkowie identyfikujący się jako Uzbecy lub Tadżycy (często zarejestrowani jako Uzbecy) oraz członkowie rodów mieszanych. W zmianach przekroju społecznego regionu znaczenie miały także przekształcenia plemion w narodowości, którym najczęściej towarzyszyła zmiana sposobu życia i gospodarowania - z koczowniczego na osiadły ${ }^{50}$.

Duży wpływ na obecną Azję Centralną ma jej wielonarodowy wymiar. Rozległą przestrzeń Azji Centralnej zamieszkuje szeroki wachlarz grup etnicznych, przy czym liczebność żadnej z nich nigdy bezwzględnie nie dominowała nad pozostałymi. Przedstawiciele największych grup etno-terytorialnych posługują się językami

47 Sengupta A., The formation of the Uzbek nation-state: A study in transition, Lanham, MD: Lexington Books, 2003, s. 48-50, 57; eadem, Frontiers into borders the transformation of identities in Central Asia, Hope India Publications, Greenwich Milennium, London 2002, s. 49, 64; Bergne P., The birth of Tajikistan: national identity and the origins of the Republic, Vol. 1 of International Library of Central Asia Studies, I.B. Tauris, London 2007, s. 7-12.

48 Lewis M. L., op. cit.

49 Abazov R., op. cit., s. 15.

50 Hotamov I., We Faded Away in Bukhara, [w:] M. Shakurzoda [red.], Tajiks, Arians and the Iranian Plateau, Teheran 2001, s. 271. 
z rodziny irańskiej i tureckiej. Wśród nich występuje ludność komunikująca się językami słowiańskimi oraz językami mniejszych grup etnicznych. Obecna heterogeniczność Azji Centralnej to efekt wymieszania rdzennej ludności regionu z migrantami napływającymi z innych rejonów Związku Radzieckiego oraz państw znajdujących się w najbliższej okolicy. Największa ich liczba przybyła do Azji Centralnej w czasach radzieckich, kiedy poszukiwano rąk do pracy w gałęziach przemysłu i rolnictwie $^{51}$. Największe rzesze deportowanych kierowano do Kazachstanu i Kirgistanu. Ludność obu republik prowadziła koczowniczy tryb życia, a bogate w minerały obszary ziemskie pozostawały niezaludnione i nieużytkowane. Stanowiły zatem idealny kierunek przymusowych migracji, który Rosja chciała wykorzystać na swoją korzyść. Zarówno ekonomiczną, jak też polityczną.

Mapa 2. Rozkład mniejszości narodowych w ZSRR w 1974 r.

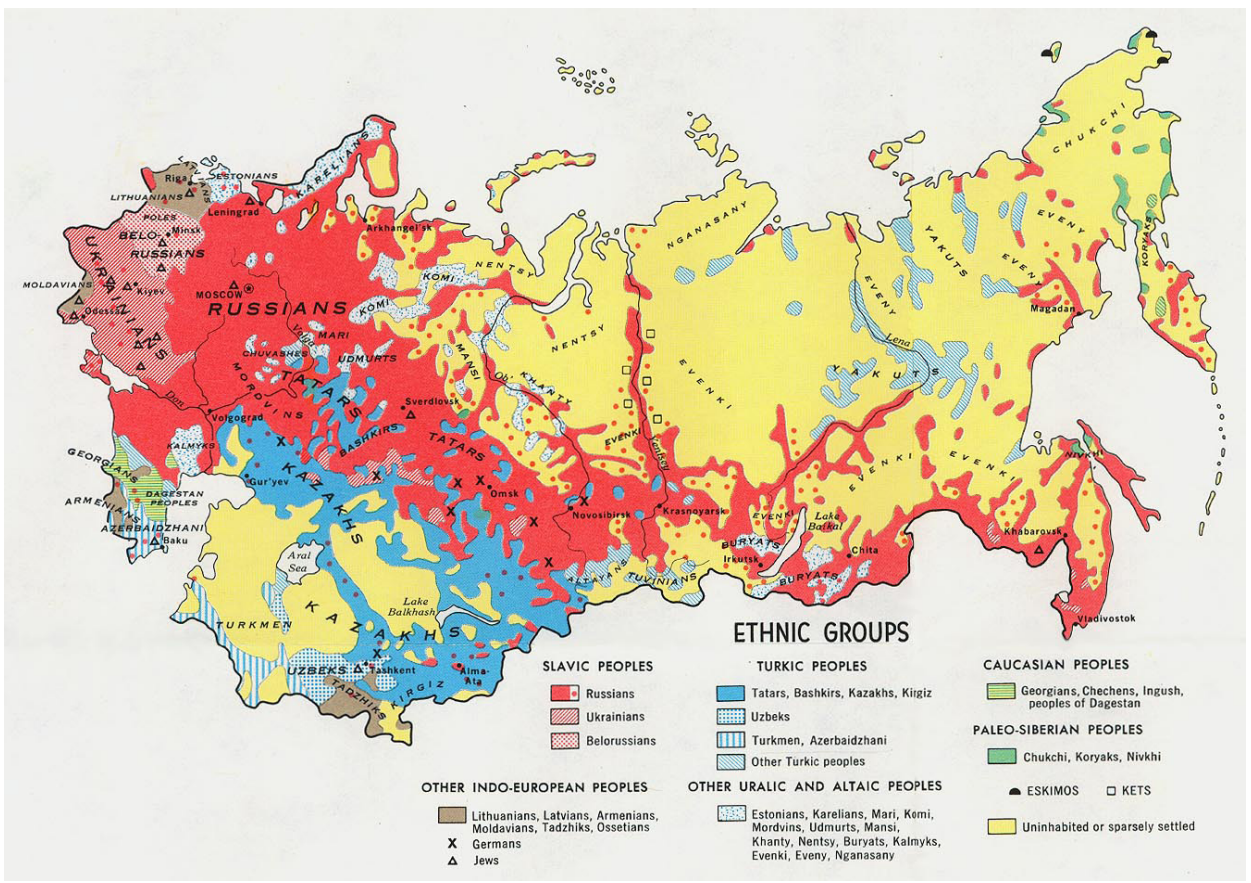

Źródło: NationMaster, strona internetowa http://maps.nationmaster.com/country/sr/1 stan z dnia 23-06-2014.

Kompozycja etniczna Azji Centralnej uległa alteracjom w wyniku następujących po sobie fal imigrantów. W pierwszej, w latach 1926-1959, kiedy realizowano

51 W czasie II wojny światowej przedsiębiorstwa wytwórcze relokowano z europejskiej części ZSRR do Kazachstanu. Wraz z przeniesieniem ośrodków przemysłu, przemieszczano też kadrę. W samym 1941 r. przesiedlono około 430 tysięcy robotników i górników. W późniejszych latach do populacji dołączyły narody prześladowane przez Stalina, co zwiększyło multietniczność republiki. Capisani G. R., Nowe Państwa Azji Środkowej, Dom Wydawniczy ELIPSA, Warszawa 2008, s. 68. 
plany industrializacji i kolektywizacji Azji Centralnej zarejestrowano napływ ludności rosyjskiej, ukraińskiej, tatarskiej, żydowskiej i europejskiej. W drugiej, będącej wynikiem polityki stalinowskich deportacji, Azja Centralna przyjęła obywateli koreańskich, niemieckich, krymskich i tureckich ${ }^{52}$.

Rosjanie i Ukraińcy byli przedstawicielami dwóch największych grup etno-terytorialnych w Azji Środkowej. Słowianie po raz pierwszy pojawili się w Kazachstanie w XVII wieku. Po zniesieniu lennictwa w $1861 \mathrm{r}$. zaczęli uprawiać ziemię i zakładać wsie na południu kraju ${ }^{53}$. Ich liczba stale rosła, przede wszystkim wśród ludności rolniczej ${ }^{54}$, osiągając szczyt na przełomie XIX i XX wieku ${ }^{55}$. Wzrost ludności słowiańskiej i jej gospodarność doprowadziły do tego, że w latach 20. i 30. XX w. wędrowne dotychczas grupy etnicznych Kazachów i Kirgizów rozpoczęły w regionie proces osiedlania.

Niemcy również migrowali na bezkresie środkowoazjatyckie. Największe ich skupiska osiedlały się w północnym Kazachstanie. Notuje się, że pierwsze większe osady niemieckie w Azji Centralnej powstały jeszcze za czasów carskich, kiedy liczba ludności pochodzenia niemieckiego nie przekraczała 7000. W wyniku rosnących rozmiarów populacji niemieckiej i chęci zinstytucjonalizowania jej obecności w ramach ZSRR, w 1924 r. powstała Niemiecka Nadwołżańska Autonomiczna Socjalistyczna Republika Radziecka, która dwa lata później skupiała ponad 50000 mieszkańców ${ }^{56}$. W 1941 r. Republika została zniesiona, a ludność niemiecka zesłana do Kazachstanu i na Syberię. Część z deportowanych zamieszkiwała okolice większych ośrodków miejskich w Kazachstanie i innych republikach środkowoazjatyckich ${ }^{57}$.

Wśród deportowanych na tereny Azji Środkowej, szczególnie w czasach II wojny światowej, były liczebne grupy etniczne, m.in. Polaków, Czeczenów, Turków Meschetyńskich, Turków Krymskich, a nawet Koreańczyków. Po raz pierwszy Koreańczycy zostali przesiedleni z rosyjskiego Dalekiego Wschodu do Kazachstanu i Azji Centralnej w 1937 roku. Podjęte działania miały charakter prewencyjny, albowiem władza radziecka podejrzewała ludność pochodzenia koreańskiego o działania szpiegowskie na rzecz Japonii ${ }^{58}$. Do tej pory Koreańczycy nie stanowią znaczącej pod kątem liczebności mniejszości etnicznej w republikach Azji Centralnej.

52 Youseff N., The Demographics of Ethnicity: Implications for Project Support in Central Asia, Washington, D.C.: World Bank August 1993, s. 2.

53 Svanberg I., Kazakshtan and the Kazakhs, [w:] G. Smith [red.], The Nationalities Question in the Post-Soviet States, s. 320.

54 Aasland A., Russians outside Russia: the New Russian Diaspora, [w:] G. Smith [red.], The Nationalities Question in the Post-Soviet States, s. 479.

55 Abazov R., op. cit., s. 16-17; Brill Olcott M., Kazakhstan: Pushing for Eurasia, [w:] R. Taras [red.], New States, New Politics: Building the Post-Soviet Nations, Cambridge University Press, Cambridge 1997, s. 550-551.

56 Diener A., Homeland as Social Construct: Teritorialization among Kazakhstan's Germans and Koreans, „Nationalities Papers”, Vol. 34, No. 2, 2006, s. 202.

57 Klüter H., People of German Descent in CIS States - Areas of Settlement, Territorial Autonomy and Emigration, „GeoJournal”, Vol. 31, No. 4, 1993, s. 419-434; Diener A., op. cit., s. 202-204.

58 Kim G., Koreans in Kazakhstan, Uzbekistan and Russia, World Diasporas Encyclopedia, Vol. 2, Kluwer 2004, s. 983-984; Diener A., op. cit., s. 213. 
Uzupełnieniem powyżej opisanego przekroju etnicznego regionu są przedstawiciele narodowości, którzy znaleźli swoją drogę ku Azji Środkowej we wcześniejszych stuleciach. Ludność pochodzenia chińskiego - Ujgurzy i Dunganie - osiedliła się w regionie w XIX wieku ${ }^{59}$. Mimo niesprzyjających warunków politycznych i gospodarczych, przedstawiciele obu grup etnicznych zdołali osiąść w regionie, zachowując swoją kulturę i język ${ }^{60}$. Dwie inne grupy etniczne to Kurdowie i Beludżowie, przedstawiciele zachodnio-irańskiej grupy językowej, którzy osiedlali się w południowej Azji Centralnej. Uciekając przed politycznym zamętem w ojczyźnie, na początku XX w. Beludżowie przybyli do Chorasanu w poszukiwaniu pracy i lepszego życia ${ }^{61}$. W 1917 r. było ich mniej niż tysiąc. Między 1923 a 1928 r. ich liczba nieco wzrosła ${ }^{62}$.

Kurdowie stanowią jedną z wielu grup etno-terytorialnych Azji Centralnej. Część z nich, zwana Kurdami Chorasańskimi ${ }^{63}$, zamieszkuje terytorium południowego Turkmenistanu. Pozostali, Kurdowie z Kaukazu, rozsiani są po Kazachstanie i Kirgistanie ${ }^{64}$.

W Azji Centralnej znalazło się również miejsce dla ludności żydowskiej. Obok Żydów aszkenazyjskich żyją rodowici przedstawiciele społeczności żydowskiej Żydzi z Buchary. Nieliczni przedstawiciele tej społeczności osiedlili się w ośrodkach miejskich wśród innych grup etnicznych ${ }^{65}$.

Mieszkańcy Pamiru nie występowali w cenzusie radzieckim jako podmiot oficjalnej grupy etnicznej do roku 1939. Dotychczas przedstawiciele różnych grup pamirskich rejestrowani byli oddzielnie. Po 1939 r. zostali wpisani w grupę Tadżyków, co jest o tyle problematyczne, iż obie grupy różnią się zarówno pod względem stosowanego języka ${ }^{66}$, jak i wyznawanej religii ${ }^{67}$. Radziecka władza traktowała Mieszkańców

59 Rezvani B., East Asian Ethnic Groups in Central Asia, „Culture and Human Being”, Vol. 4, No. 2, 2008, s. 164-169; Svanberg I., Kazakhstan and the Kazaks, s. 325.

60 Rezvani B., East Asian Ethnic Groups in Central Asia, s. 168-169.

61 Kraina historyczna w Azji Środkowej, położona na terenie dzisiejszego wschodniego Iranu, zachodniego i środkowego Afganistanu oraz częściowo na terytorium Tadżykistanu, Turkmenistanu i Uzbekistanu. Encyclopedia Britannica, http://www.britannica.com/EBchecked/topic/316850/Khorasan stan $\mathrm{z}$ dnia 23-06-2014.

62 Wixman R., The Peoples of the USSR: An Ethnographic Handbook, M.E. Sharp, New York \& London 1984, s. 25-26.

63 Kurdowie są spokrewnieni z mieszkańcami przylegającego do Azji Centralnej irańskiego regionu Chorasan.

64 Olson J. S. [red.], An Ethnohistorical Dictionary of the Russian and Soviet Empires, L.B. Pappas \& N.C.J. Pappas, CT: Greenwood Press, Westport 1994, s. 409; Madih A. A., The Kurds of Khorasan, „Iran and the Caucasus”, Vol. 11, No. 1, 2007, s. 11-31.

65 Abazov R., op. cit., s. 75.

66 Tadżycy posługują się językiem tadżyckim, będącym dialektem perskim, należącym do południowo-zachodniej gałęzi języków irańskich; z kolei Mieszkańcy Pamiru komunikują się wschodnio-irańskimi językami i dialektami należącymi do gałęzi języków południowo-wschodnich. Obie formy językowe są dla ich przedstawicieli niezrozumiałe.

67 Tadżycy są Sunnitami, mieszkańcy Pamiru wyznają Ismailizm. Rezvani B., Ethno-territorial conflict and coexistence in the Caucasus, Central Asia and Fereydan, Amsterdam University Press, 2013, s. 160 . 
Pamiru jak oddzielną grupę etniczną, którą uwzględniła w procesie delimitacji, tworząc w 1925 r. Górskobadachszański Obwód Autonomiczny.

Największą grupę etniczną stanowili Rosjanie. W połowie XIX w. Rosjanie zaczęli migrować w kierunku azjatyckim. Masowe migracje towarzyszyły ważnym wydarzeniom w ówczesnej Rosji - carskiej ekspansji w Azji Środkowej, reformie rolnej Piotra Stołypina, II wojnie światowej i konstrukcji nowej, wielkiej Azji Centralnej zaplanowanej przez Chruszczowa. Do końca lat 80. XX w. około dziesięciu milionów Rosjan zamieszkiwało republiki regionu. Największe skupiska znajdowały się w najbliższym terytorialnie i kulturowo Kazachstanie - 5 mln, i Uzbekistanie - 2 $\mathrm{mln}{ }^{68}$. Od początku Rosjanie zajmowali dominujące pozycje w szeregach społecznych, politycznych i ekonomicznych, czując się jak w swojej ojczyźnie, uważając rdzennych mieszkańców Azji Centralnej za ograniczonych, zacofanych i agresywnych. Uprzywilejowana rola przysługiwała Rosjanom do czasu, kiedy republiki uzyskały niepodległość, a narodowość rosyjska znalazła się po drugiej stronie granicy jako nietytularna mniejszośćc ${ }^{6}$.

\section{Kontrowersje terytorialne}

Władza rosyjska niestrudzenie torpedowała aspiracje niepodległościowe w regionie, prowadząc politykę podziału nacjonalistów. Tuż po umocnieniu władzy i kontroli nad terytorium ówczesnego Imperium Carskiego, Sowieci wprowadzili rozbudowany program politycznej i społecznej reorganizacji Azji Centralnej, tzw. narodową delimitację. Był to kamień węgielny położony pod proces budowy państwowości radzieckiej oparty na założeniach terytorializacji i narodowości. Wszystkie szczeble władzy, eksperci oraz prorosyjscy przedstawiciele lokalnych grup etnicznych zostali zaangażowani w proces przemieszczania instytucji terenowych oraz ludności, która zamieszkiwała dane obszary.

Terytorialna delimitacja miała na celu zdefiniowanie terytorium w odniesieniu do rozmieszczenia osiadłych i koczowniczych społeczności. Wyznaczanie granic w tej części Związku Radzieckiego było o tyle trudne, że ludy wędrowne i osiadłe współistniały tam ze sobą przez wieki. W konsekwencji wybrane rozwiązania przysporzyły tyle samo kłopotów, ile miały regulować.

Podział terytorialny Azji Centralnej był efektem radzieckiej interpretacji i implementacji prawa narodów do samostanowienia. Inicjatorem tej polityki był W. Lenin (1917-1924), architektem - J. Stalin (1924-1953). W 1924 r., kierując się zasadami polityki kolonialnej, dekretem O parcelacji narodowo-państwowej republik Azji Środkowej ${ }^{70}$ administracja radziecka rozpoczęła przymusową demarkację granic, w myśl której ZSRR podzielono wzdłuż polityczno-etnicznych linii. Wszystko odbyło się przed narodowym cenzusem zaplanowanym na 1926 r. ze znikomą wiedzą na

68 Zongqi Z., op. cit., s. 184.

69 Ibidem.

70 Szczepanik E., Radzieckie republiki Azji Środkowej 1917-1941: dzieje, gospodarka, społeczeństwo, Zakład Narodowy im. Ossolińskich, Wrocław 1987, s. 55 i nast. 
temat regionu i przeświadczeniem, że ów proces będzie miał charakter prowizoryczny, albowiem delimitacja przewidywała rewizję granic ${ }^{71}$.

Deklaracja Praw Ludu Pracującego i Wyzyskiwanego ${ }^{72}$ oraz późniejsze akty w randze ustawy zasadniczej ${ }^{73}$ precyzowały formę Związku Radzieckiego jako hierarchicznie zorganizowaną strukturę federalną, oraz zakres zróżnicowanego potencjału przywilejów autonomicznych przysługujących jego podmiotom praw - największe prawa i przywileje otrzymywały najwyżej usytuowane jednostki federalne. A jako takie uplasowane zostały Socjalistyczne Republiki Radzieckie (SRR), zwane również republikami związkowymi; następne w klasyfikacji były, odpowiednio Autonomiczne Socjalistyczne Republiki Radzieckie (ASRR), Autonomiczne Obwody (obłast, znane także jako autonomiczne prowincje); oraz Autonomiczne Okręgi (okrug, występujące też pod nazwą regonów narodowych). Zasadniczo wszystkie terytoria autonomiczne stworzono i zdelimitowano, zamykając w ich granicach tytularne grupy etniczne. Nie było to jednak jednoznaczne z tym, że dana grupa tytularna stanowiła w państwie większość populacji. Demarkacja granic była jednym z procesów, który miał ugasić narodową solidarność, a w jej miejscu rozwinąć zróżnicowanie klasowe. Tożsamość lokalnej ludności Azji Środkowej wpisywano w tożsamość jednej z pięciu głównych tożsamości narodowych regionu ${ }^{74}$. Co więcej, zdając sobie sprawę $\mathrm{z}$ tego, że przeprowadzany cenzus będzie miał wpływ na zmiany w regionalizacji i delimitacji, przedstawiciele niektórych grup tytularnych próbowali manipulować jego wynikami, przypisując do swojej grupy ludność innego pochodzenia etnicznego ${ }^{75}$. W pierwszych latach władzy bolszewików na terytorium Turkiestanu i Wielkiego Stepu powołano do życia cztery podmioty, które wraz ze starannie układanymi granicami wyewoluowały do postaci Socjalistycznych Republik Radzieckich ${ }^{76}$.

Od 1918 r. dzisiejszy Kirgistan był częścią Turkiestańskiej Autonomicznej Republiki Radzieckiej77. W 1920 r., kiedy na terytorium Kazachstanu zagościła

71 Hirsch F., op. cit., s. 161-163.

72 Lenin W., Powne zibrannia tworiw, t. 35, Kyjiw 1981, s. 277; Czuma I., Konstytucja Rosji Sowieckiej, Krakowska Spółka Wydawnicza, Kraków 1923.

73 Konstytucja ZSRR z 1936 r., strona internetowa https://constitutii.files.wordpress.com/2013/01 /1936-en.pdf stan z dnia 01-08-2014; Konstytucja Zwiazku Socjalistycznych Republik Radzieckich, tłum. S. R. Dobrowolski, Warszawa 1977; Lityński A., Prawo Rosji i ZSRR 1917-1991, czyli historia wszechzwiązkowego komunistycznego prawa (bolszewików). Krótki kurs, Wydawnictwo C.H. Beck, Warszawa 2010, s. 19-103; Kowalski J., Konstytucja Federacji Rosyjskiej a Rosyjska i Europejska tradycja konstytucyjna, Iuris Polskie Wydawnictwo Prawnicze Sp. z o.o., Warszawa-Poznań 2009, s. 71-95.

74 Analogicznie, dotychczasowe spory lokalne urastały do poziomu konfliktów narodowych.

75 Hirsch F., op. cit., s. 123-131.

76 Bodio T., Załęski P., op. cit., s. 111; Sagdullaev A. S., Starożytne korzenie państwa Uzbeków, [w:] T. Bodio [red.], Uzbekistan: historia, społeczeństwo, polityka, Wydawnictwo Elipsa, Warszawa 2001, s. 41-50; Capisani G. R., op. cit., s. 154-164.

77 Gleason G., Uzbekistan: The Politics of National independence, [w:] I. Bremmer, R. Taras [red.], Soviet States, New Politics: Building the Post-Soviet Nations, Cambridge University Press, Cambridge 1997, s. 336. 
na dobre władza radziecka, rozległe tereny Wielkiego Stepu zostały zinstytucjonalizowane w granice Kirgiskiej (lub Kazachskiej) Autonomicznej Socjalistycznej Republiki Radzieckiej. Z kolei region Turkiestanu - w Turkiestańską Autonomiczną Socjalistyczną Republiką Radziecką oraz Ludowe Republiki Radzieckie Chorezmu i Buchary (później przekształcone w socjalistyczne) ${ }^{78}$. W szystkie podmioty państwowe znajdowały się w bezpośredniej sferze wpływów władzy sowieckiej. W 1924 r. decyzją administracyjną stworzono Kara-Kirgiski (od 1925 r. Kirgiski) Obwód Autonomiczny przemianowany w 1926 r. na Kirgiską Autonomiczną Socjalistyczną Republikę Radziecką ${ }^{79}$. W tym samym roku rozwiązano Socjalistyczne Republiki Radzieckie Chorezmu i Buchary, które wraz z Turkiestańską SRR podzielono na dwie republiki związkowe - Uzbekistanu i Turkmenistanu. Po nieudanej próbie zjednoczenia ludności osiadłej w granicach Uzbekistanu, na części jego terytorium utworzono Tadżycką Autonomiczną Socjalistyczną Republikę Radziecką, która w 1929 została ostatecznie odłączona od Uzbeckiej SRR i stała się częścią ZSRR jako Tadżycka Socjalistyczna Republika Radziecka ${ }^{80}$. W 1936 r. do Uzbeckiej SRR przyłączono powstałą w 1932 r. w ramach Rosyjskiej FSRR Karakałpacką Autonomiczną Socjalistyczną Republikę Radziecką ${ }^{81}$. W 1936 r. Kazachską i Kirgiską ASSR podniesiono do rangi republik socjalistycznych ${ }^{82}$. Ustalone w 1924 r. granice nie stały się prawomocne aż do 1936 r., kiedy Tadżykistan, Kazachstan i Kirgistan otrzymały status republik związkowych ${ }^{83}$.

Delimitacja odegrała znaczącą rolę w ukształtowaniu współczesnej Azji Centralnej oraz konstrukcji ówczesnej radzieckiej tożsamości narodowej. Opierając się na założeniu, które promuje samookreślenie tożsamości narodów na podstawie przynależności terytorialnej, władza radziecka przydzieliła konkretnym grupom etnicznym terytoria zróżnicowane pod kątem cech administracyjnych (autonomie, okręgi, republiki związkowe) i pielęgnowała ideę zwierzchnictwa danej ludności tytularnej nad przyznanym obszarem ${ }^{84}$. Sowiecki aparat państwowo-administracyjny dopilno-

78 Sagdullaev A. S., op. cit., s. 41-50; Capisani G. R., op. cit., s. 154-164; Szczepanik E., op. cit., s. 44 i nast.

79 Gleason G., op. cit., s. 336.

80 Delimitacja odbyła się na podstawie tych samych niejasnych kryteriów natury etnicznej i językowej, na podstawie których wyodrębniono rasę tadżycką w XIX wieku.

81 W latach 1924-1930 Karakałpacki Obwód Autonomiczny znajdował się pod zwierzchnictwem Kazachstanu i jurysdykcją Moskwy. Zorganizowanie autonomicznej republiki Karakałpaków było elementem prowadzonej, zwłaszcza w początkowym okresie istnienia ZSRR, polityki tzw. korienizacji, tj. przyznawania autonomii nierosyjskim narodom dawnego Imperium, wcześniej dyskryminowanym i wynaradawianym przez carat.

$82 \mathrm{Z}$ historycznego punktu widzenia południowe tereny Kazachstanu są bliżej związane z pozostałymi republikami Azji Centralnej, aniżeli z północą kraju. Kilka powiatów i okręgów miejskich, w granicach których znajdowała się przeważająca liczba Uzbeków, zostało przydzielonych administracji Kazachstanu.

83 Gleason G., op. cit., s. 336.

84 Zevelev I., Russia and Its New Diasporas, Washington D.C.: United States Institute of Peace Press, 2001, s. 34-39. 
wał, by każda z nowo nakreślonych republik charakteryzowała się zróżnicowanym etnicznie przekrojem społecznym, co miałoby zapobiec rozwojowi potencjalnych tendencji antyradzieckich. Istotnym warunkiem delimitacji było również wyznaczenie w każdej republice jednej granicy, która dzielona byłaby z państwem zewnętrznym, co na wypadek secesji któregokolwiek z narodów miało chronić jedność Związku Radzieckiego. Konstytucja ZSRR z 1977 r. dopuszczała prawo republik związkowych do secesji. Zgodnie z zapisami ustawy zasadniczej tylko republiki związkowe były pełnoprawnymi członkami ZSRR, więc tylko im, jako podmiotom federacji, przysługiwała technicznie pojmowana niepodległość, z której wywodziło się prawo do secesji. Było to jednak założenie czysto teoretyczne, albowiem jakakolwiek forma oderwania się od ZSRR wymagała zgody władzy centralnej ${ }^{85}$.

Mapa 3. Azja Centralna w czasach Imperium Rosyjskiego

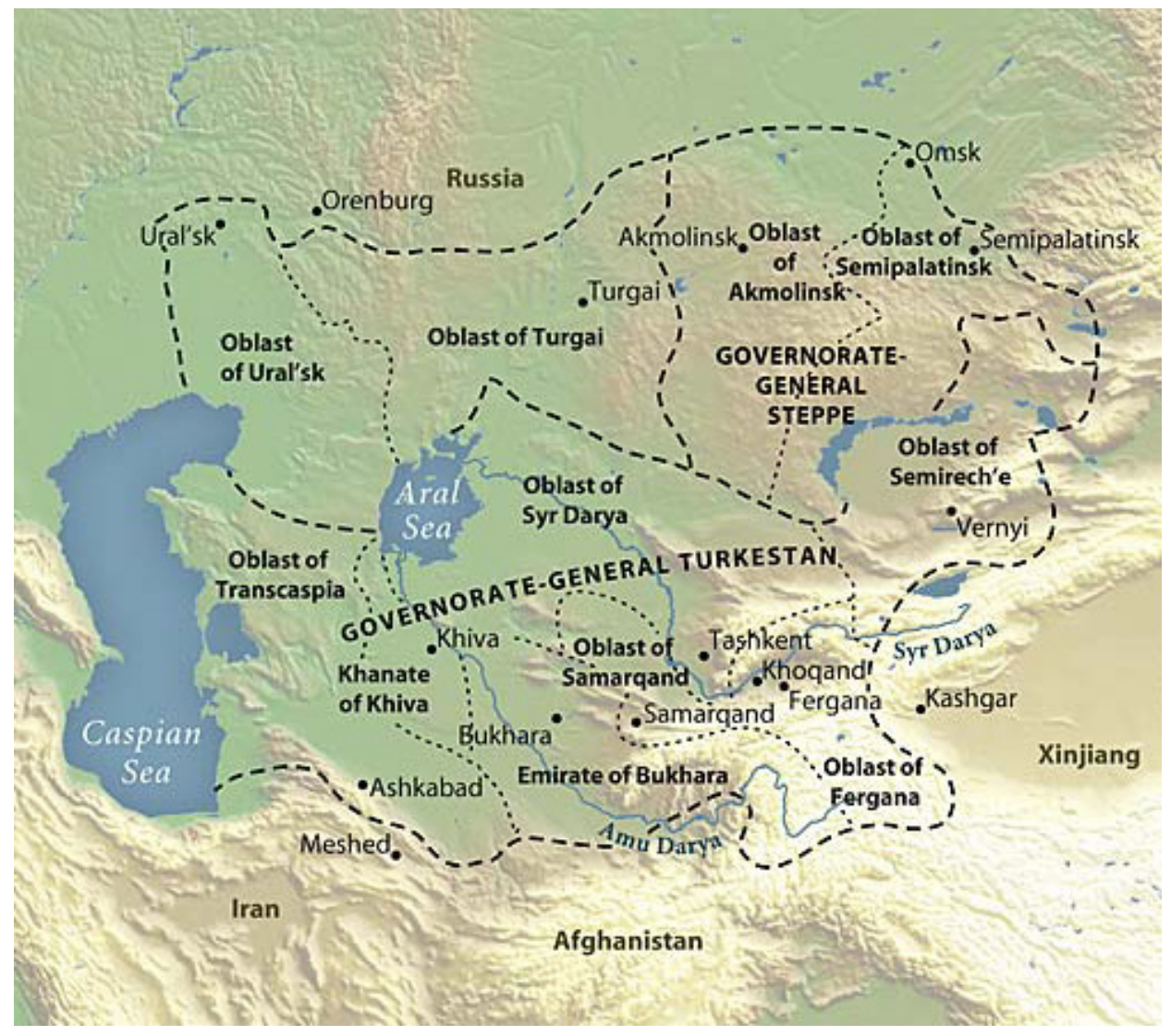

Źródło: Metropolitan Musuem of Arts, strona internetowa http://www.metmuseum.org/toah/ ht/10/nc/map_czar.htm stan z dnia 23-06-2014.

85 Blank S., Soviet Reconquest of Central Asia, [w:] H. Malik [red.], Central Asia: Its Strategic Important and Future Prospects, St. Martin's Press, New York 1994, s. 54-55. 
Finalizacja demarkacji w 1936 r. nie kończyła procesu zmian w kompozycji etnicznej Azji Środkowej. Arbitralnie przeprowadzona delimitacja nie korespondowała z granicami kulturowymi czy językowymi, pozostawiając w efekcie wiele narodowości poza historycznymi granicami, np. w enklawach ${ }^{86}$. Ponadto, komisja delimitująca została poinstruowana, by każda nowo powstała republika miała w swoich granicach duże ośrodki miejskie ${ }^{87}$. Co więcej, istnieją przesłanki świadczące o tym, że proces delimitacji przeprowadzono z myślą o interesach regionalnych Uzbekistanu. W wyniku czego, prawie wszystkie większe miasta Azji Centralnej znalazły się w granicach nowo powstałej republiki uzbeckiej. W części Kotliny Fergańskiej, która jest pod administracją Uzbekistanu, poza ludnością uzbecką znajdują się również mieszkańcy Kirgistanu i Tadżykistanu. Co jakiś czas Uzbekistan wysuwa żądania terytorialne co do całej Kotliny Fergańskiej, w granicach której znajduje się kirgiski obwód oszski - zaludniony w większości przez narodowość uzbecką - oraz tadżycki okręg Chodżentu. Tadżykistan otrzymał rozwinięte północne terytoria z miastem Chodżent usytuowanym w zachodniej części Kotliny Fergańskiej w ramach zadośćuczynienia utracie historycznych centrów kultury tadżyckiej - Buchary i Samarkandy, które znalazły się w granicach Uzbekistanu. Ówcześnie nazywany Leninabadem, Chodżent pozostawał w strefie wpływów politycznych Uzbekistanu i ZSRR ${ }^{88}$, co tylko pogłębiało zależność Tadżykistanu od tych dwóch podmiotów państwowych ${ }^{89}$. Na przestrzeni lat $\mathrm{z}$ charakterystyczną cyklicznością w Uzbekistanie pojawiają się głosy przemawiające za historyczną, kulturową i etniczną przynależnością terytorialną południowego Kazachstanu ${ }^{90}$ i wschodniego Turkmenistanu ${ }^{91}$. Kolejnym przykładem problematycznych granic są północne tereny Kazachstanu od XVI w. należące do Rosji. Wielu etnicznych Rosjan, w tym znaczny procent zamieszkujących północ Kazachstanu, nadal postrzega ten kraj jak właściwą historycznie ziemię ojczy-

86 Za przykład może służyć Soch, zlokalizowany w Kirgistanie, ale oficjalnie należący do Uzbekistanu, w którym 95\% mieszkańców stanowią Tadżycy, a 5\% Kirgizi. Roy O., The New Central Asia. The Creation of Nations, Londyn-Nowy Jork 2000, s. 68-71; Imomov A., Territorial and Water Conflicts in Central Asia: A View from Tajikistan, „Central Asia and Caucasus”, Vol. 14, Issue 2 (2013), s. 2.

87 Zanca R., When Democracy Makes for Failing State: Inter-Ethnic Violence in Kyrgyzstan, „The Illinois International Review", Issue 12, Fall 2010.

88 Ze względu na wysoki stopień rozwoju ekonomicznego oraz znaczną rusyfikację północy kraju, elity polityczne republiki były wspierane przez władzę radziecką. Dało to początek dominującej od $1945 \mathrm{r}$. tendencji politycznej, w ramach której aparat państwowy opanowany był przez obywateli północy kraju. Tuż po uzyskaniu niepodległości, próby podziału władzy i zasobów państwa między partie polityczne północy i południa były jednym z pierwszych przyczyn wybuchu wojny domowej w Tadżykistanie. Miejscowy podział władzy ilustruje tadżyckie powiedzenie: Tadżyckie kobiety z północy rodzą tylko liderów i uczonych, natomiast te z południa - robotników i rolników. Tabyshalieva A., op. cit., s. 4.

89 Chodżent zamieszkiwała znacznych rozmiarów mniejszość uzbecka paradoksalnie stanowiąca w mieście większość, a region miasta charakteryzował się wysokim stopniem rozwoju gospodarczego i postępującą rusyfikacją. Wielu obywateli Uzbekistanu uważa, że Tadżycy to Uzbecy, którzy posługują się językiem perskim. W istocie, pierwotnie nakreślone granice republik włączały autonomiczną republikę Tadżykistanu w terytorium Uzbeckiej republiki związkowej.

90 Rumer B. Z., Soviet Central Asia: A Tragic Experiment, London 1989, s. 18.

91 Brill Olcott M., Central Asia’s Post-Empire Politics, „Orbis”, Vol. 36, No. 2, Spring 1992, s. 256. 
stą. Najsłynniejszy rosyjski nacjonalista, Aleksander Sołżenicyn, twierdził nawet, że północ Kazachstanu to południe Syberii, tym samym integralna część Rosji92.

Rozkład tożsamości etnicznej ludów Azji Centralnej określony na lata przed Rewolucją okazał się podstawą post-demarkacyjnej rzeczywistości republik. W wypadku Kazachstanu transformacja z tożsamości etnicznej do narodowej odbyła się już na poziomie lokalnym. To samo, choć w mniejszym stopniu, miało miejsce w wypadku Turkmenistanu. Ludność, która dotychczas prowadziła osiadły tryb życia, zajmowała się rolnictwem w ten sam sposób, ale posługiwała się różnymi dialektami języka tureckiego i perskiego, rozdzielono między Uzbeków i Tadżyków. Z kolei ludy koczownicze, które charakteryzowały odmienne formy migracji, otrzymały paszporty kirgiskie i kazachskie. Bodio i Załęski zwracają istotną uwagę na fakt, iż „decyzje władzy radzieckiej o przyznaniu statusu republiki, republiki autonomicznej czy nawet obwodu autonomicznego było pierwszymi, które owocowały quasi-państwowościami narodowymi w dziejach nowożytnych" ${ }^{\prime 3}$. Warto też w tym miejscu wspomnieć, iż polityka narodowościowa wraz z procesem przymusowej delimitacji i budowy nowego narodu budziły niepokój i antypatie wśród rdzennych mieszkańców republik Azji Centralnej, którzy tego rodzaju działania odbierali jako próbę naruszenia status quo interesów mniejszości etnicznych. $Z$ drugiej strony grupy etniczne Azji Centralnej miały niezbyt liczne, będące w zdecydowanej mniejszości, elity narodowe, dla których tożsamość narodowa miała charakter pierwszorzędny ${ }^{94}$.

W trakcie II wojny światowej i tuż po niej Stalin skorygował część wcześniejszych decyzji, w tym deportował ludzi oraz ponownie wyznaczył granice ZSRR ${ }^{95}$. Chcąc zachować równowagę narodowościową w szeregach władzy lokalnej, Sowieci wykorzystywali imigrację i przesiedlenia miejscowej ludności. Rozpraszało to siłę i zasięg władzy poszczególnych grup etnicznych, doprowadzając do ich osłabienia. Po śmierci Stalina, Chruszczow przywrócił większość uprzednio obowiązującej w 1936 r. etnoterytorialnej mapy ZSRR.

Wszelkie decyzje odnośnie do kreacji wewnętrznych i zewnętrznych granic ZSRR zostały podjęte przez władze w Moskwie bez konsultacji z ludnością rdzenną, a tym bardziej kierowania się właściwościami demograficznymi czy historycznymi regionu. W naradach poprzedzających delimitację regionu brali jedynie udział komunistyczni przedstawiciele Azji Centralnej, którzy wzywali do zwiększenia

92 Zevelev I., Russia's Future: Nation or Civilization? - Collapse of the Soviet Union and the 'Russian Question', „Russia in Global Affairs”, Vol. 7, No. 4 (2009), s. 82.

93 Bodio T., Załęski P., op. cit., s. 112.

94 Brill Olcott M., Nation Building and Ethnicity in the Foreign Policies of the New Central Asian States, [w:] R. Szporluk [red.], National Identity and Ethnicity in Russia and the New States of Eurasia, „The International Politics of Eurasia”, Vol. 2, M. E. Sharpe, New York 1994, s. 212.

95 W 1946 r. Rada Ministrów Związku Radzieckiego podjęła uchwałę, w myśl której 151600 hektarów ziemi w Kazachstanie wydzierżawiono Uzbekistanowi na 10 lat. Z kolei Kazachstan otrzymał od Uzbekistanu 8500 hektarów z terminem dzierżawy do 1991 roku. Na początku 2000 r. Uzbekistan zaczął samodzielnie regulować swoją północą granicę, doprowadzając do jednego z wielu sporów terytorialnych między dwoma republikami Azji Centralnej. Zongqi Z., op. cit., s. 187. 
powierzchni terytorialnej tytularnym narodowościom, z którymi się utożsamiali ${ }^{96}$. Nakreślone granice zmieniły przestrzeń polityczną i społeczną Azji Centralnej, wpływając na układ władzy i przynależności państwowej. Członkowie dominujących narodowości - np. Uzbecy - zdobyli dostęp do zasobów ziemi, wody, władzy i rozpoczęli przewartościowywanie dotychczasowych interesów narodowych przez pryzmat kategorii narodowych. Tymczasem przedstawiciele mniejszości narodowych - np. Kazachowie zamieszkujący w Uzbeckiej SSR - doświadczali dyskryminacji, przymusowej asymilacji oraz utraty ziemi i środków do życia. Sytuację pogarszały nieustanne zmiany położenia granic prowadzące do rosnących w siłę konfliktów narodowych ${ }^{97}$. Wszelkie działania władzy radzieckiej zmierzały ku antagonizowaniu narodów w Azji Centralnej, a tym samym zminimalizowaniu szans na ich niezależność. Zdaniem Oliviera Roy’a służyły temu przede wszystkim skrupulatnie ułożone granice nieposiadające żadnego usprawiedliwienia geograficznego, etnicznego czy gospodarczego ${ }^{98}$.

Wykorzystując geograficzną rekonfigurację, władza radziecka zdołała wykreować w granicach Azji Środkowej mozaikę etniczną, której kompozycja miała zapobiec jakiejkolwiek jedności politycznej wśród grup etnicznych, co mogłoby w bezpośredni sposób zagrozić reżimowi Moskwy. Zróżnicowana matryca etniczna (narodowościowa) zapobiegała potencjalnemu wybuchowi buntu wobec scentralizowanej władzy. A zdecentralizowana gospodarka dawała złudne poczucie równości całego społeczeństwa ${ }^{99}$.

Współcześnie występujące spory terytorialne w Azji Centralnej są dziedzictwem „plastycznie” realizowanej przez ZSRR demarkacji, w trakcie której nie poświęcono uwagi na wielowiekowe więzi etniczne, kulturowe czy religijne, dostęp do surowców i zasobów - przede wszystkim wodę. Wynikiem tak przeprowadzonych zmian są występujące obecnie sporne tereny, prawa do których rości sobie wiele grup etnicznych jednocześnie, a które stały się zarzewiem konfliktów narodowościowych współczesnej Azji Centralnej. Niektórzy badacze twierdzą, iż mimo wszystkich swoich kontrowersyjnych działań w Azji Centralnej, władza radziecka wprowadziła w regionie względną stabilizację polityczną i równowagę między poszczególnymi grupami etnicznymi oraz zagwarantowała w miarę przewidywalną przyszłość. Inni podkreślają, że w rezultacie - w dobie niepodległości każde z państw zaczęło zgłaszać roszczenia terytorialne do ziem znajdujących się w granicach republik sąsiedzkich. Jakby nie tłumaczono tego procesu, szereg nieuregulowanych problemów terytorialnych nadwyrężył poziom zaufania między republikami i obniżył próg bezpieczeństwa w regionie. Burząc pierwotny zamysł władzy centralnej, doce-

96 Zanca R., op. cit.

97 Hirsch F., op. cit., s. 105, 163-173.

98 Roy O., op. cit., s. 68-71.

99 Collier zaprezentował pogląd, w którym stwierdził, że wyższy wskaźnik różnorodności etnicznej zmniejsza ryzyko działań powstańczych. Collier P., The Political Economy of Ethnicity, [w:] B. Pleskovic, J. E. Stiglitz, Annual World Bank Conference on Development Economics 1998, The World Bank, Washington, D.C. 1999, s. 395. 
lowo nowo powstałe granice miały jedynie odgrywać rolę wewnątrzpaństwowych mechanizmów kontrolnych.

W literaturze przedmiotu występują dwa nurty opisujące proces delimitacji w Azji Centralnej. Pierwszy negatywny zakłada, iż władza radziecka, realizując politykę „dziel i rządź”, tłumiła prawdziwą tożsamość narodową ludów Azji Centralnej, dezintegrując i wpisując je w wymyślone kategorie narodowe ${ }^{100}$. Drugi z kolei podkreśla pozytywną rolę Rosjan w działaniu zmierzającym do stworzenia przynależności narodowej w ówcześnie panującej próżni narodowej regionu ${ }^{101}$. Analizując fakty historyczne, można znaleźć uzasadnienie dwóch wspomnianych poglądów. W teorii Związek Radziecki miał spełniać funkcje systemu federalnego $\mathrm{z}$ władzą skupioną $\mathrm{w}$ centralnych ośrodkach państwa ${ }^{102}$. W praktyce pozostawał sumą aspirujących do względnej niezależności podmiotów państwowych.

\section{Tożsamość narodowa w olkresie radzieckim}

Kiedy Rosjanie podbili Azję Środkową w drugiej połowie XIX w., wprowadzili $\mathrm{w}$ regionie sporo zamieszania $\mathrm{w}$ dotychczasowych relacjach etnicznych i towarzyszącym im trybie życia. W chwili zajęcia Azja Centralna spełniała funkcję dostawcy surowców na wielki rynek rosyjski i utrzymywała się dzięki subwencjom z Moskwy. W następnych dekadach problemem okazała się implementacja socjalizmu na terenie, gdzie nie istniała klasa robotnicza, a wiedzę uniwersalną czerpano z tekstów religijnych. Powołując do życia Związek Radziecki, bolszewicy kategorycznie odcięli się od carskiej przeszłości i wprowadzili nowy etniczny, religijny i terytorialny system związkowy. W przeciwieństwie do Imperium Carskiego nowo powstały Związek Radziecki instytucjonalizował wielonarodowość ${ }^{103}$.

Na proces tworzenia tożsamości narodowej w ZSRR miała duży wpływ dualność struktury państwowej, którą Smith określił mianem „federalnego kolonializmu” - ustroju, który zawierał w sobie cechy obu wspomnianych systemów ${ }^{104}$. Władza

100 Chokaiev M., Turkestan and the Soviet Regime, „Journal of the Royal Central Asian Society”, 18 (1931), s. 414.

101 Allworth E., The 'Nationality' Idea in Czarist Central Asia, [w:] E. Goldhagen [red.], Ethnic Minorities in the Soviet Union, Praeger, New York 1968, s. 247.

102 Martin T., The Affirmative Action Empire: Nations and Nationalism in the Post-Soviet Union, 1923-1939, s. 13.

103 Terminu „mniejszość” nie używano ze względu na negatywne konotacje. Zamieniono go $\mathrm{z}$ „narodowością". I w ogólnym rozrachunku różne narodowości ZSRR nie doświadczały umyślnej dyskryminacji ekonomicznej i politycznej. Z kilkoma wyjątkami. Była to kontynuacja doktryny Marksa - Lenina i polityki Partii Komunistycznej, które były ukierunkowane na wprowadzenie równości wśród przedstawicieli wszystkich narodów ZSRR. Zachęcano jednocześnie do pielęgnowania występujących między grupami etnicznymi różnic kulturowych. Jourek O. N., Ethno - political Conflicts in Post Communist Societies: Prospects for Resolution and Prevention in the Context of International Law, Harvard University, John F. Kennedy School of Government, Cambridge 1999, s. 22.

104 Smith G., Post-colonialism and Borderland Identities [w:] G. Smith, V. Law, A. Wilson, A. Bohr, E. Allworth [red.], Nation-Building in the Post-Soviet Borderlands: The Politics of National Identities, Cambridge University Press, Cambridge 1998, s. 4. 
ZSRR nieustannie dążyła do integracji miejscowej ludności z kulturą i wielonarodowością całego państwa rosyjskiego, wykorzystując w promocji radzieckiej tożsamości narodowej czynniki demograficzne i językowe. W tym celu posługiwała się ideologią internacjonalizmu i komunizmu, równolegle wspierała osadnictwo Słowian i procesy rusyfikacji. Najbardziej podatne na zmianę okazały się dawne ludy koczownicze - Kazachowie i Kirgizi, gdzie osiedlało się najwięcej Słowian, najmniej - mieszkańcy południowych krańców Azji Centralnej, które były w większym stopniu zislamizowane.

Najtrwalszym dziedzictwem ZSRR był podział terytorialny Azji Środkowej. Wprowadzone zmiany wpłynęły na tempo tworzenia się narodów tytularnych, jednocześnie niosąc ze sobą postępującą separację i rozpad wspólnej dotychczas przestrzeni kulturowej oraz nierównomierny podział etnosów. Początkowo rodziło to pewien poziom niezadowolenia wśród poszczególnych ludności, np. Tadżyków z przyznania Uzbekistanowi Samarkandy i Buchary, ale nie zagrażało stabilności i jedności Związku. Efekty tak przeprowadzonej delimitacji stały się jednak poważnym źródłem narastających sporów i konfliktów.

Paradoksalnie, polityka Moskwy miała być urzeczywistnieniem idei samookreślenia narodów Woodrowa Wilsona ${ }^{105}$. Ale zamiast zwiększać autonomię rdzennej ludności, głównym celem realizowanej polityki miało być przezwyciężenie dzielących je różnic w drodze zjednoczenia wszystkich narodowości pod wspólną socjalistyczną i radziecką tożsamością ${ }^{106}$. W tym wypadku nacjonalizm - rozumiany jako przekonanie, że naród jest najważniejszą formą uspołecznienia, a tożsamość narodowa najważniejszym składnikiem tożsamości jednostki - odbierany był jako naturalny stan przed modernizacją państwa i stworzeniem jednolitego narodu sowieckiego ${ }^{107}$. Na podstawie zestawu kryteriów: języka, terytorium, kultury i ekonomii, piętnaście grup narodowości otrzymało status Socjalistycznych Republik Radzieckich ${ }^{108}$. W granicach tych republik znajdowały się, w kolejności malejącej, 20 autonomicznych socjalistycznych republik radzieckich, osiem autonomicznych regionów oraz 10 autonomicznych obszarów ${ }^{109}$. Niestety jedynie 53 z ponad 100 narodowości zostało oficjalnie uznanych na XII Kongresie Partii Komunistycznej w $1923 \mathrm{roku}^{110}$.

105 Woodrow Wilson zastosował termin „samookreślenia narodów” w kontekście budowy państwowości po I wojnie światowej. Myślał przy tym o samookreśleniu jako prawie przysługującym ludności ówczesnych kolonii.

106 Coppieters R., Form and Content in Soviet and Post-Soviet Nationality and Regional Policies, [w:] M. Waller, B. Coppieters, A. Malashenko [red.], Conflicting Loyalties and the State in Post-Soviet Russia and Eurasia, Frank Cass Publishers, London 1998, s. 18.

107 Bremmer I., Reassessing Soviet Nationalities Theory, s. 9.

108 Bohr A., Turkmenistan and the Turkmen, [w:] G. Smith [red.], Nationalities Question in the Post-Soviet States, Longman, London 1996, s. 349.

109 Bremmer I., Reassessing Soviet Nationalities Theory, s. 5.

110 Appleby I., Uninvited guests in the communal apartment: nation formation processes among unrecognized Soviet nationalities, „Nationalities Papers”, Vol. 38, No. 6, 2010, s. 847. 
Stalin w prosty i klarowny sposób wyjaśnił, opierając się na założeniach marksizmu-leninizmu, co składa się na definicję narodu:

Naród to wytworzona historycznie, trwała wspólnota ludzi, powstała na gruncie wspólnoty języka, terytorium, życia ekonomicznego i układu psychicznego, przejawiającego się we wspólnocie kultury ${ }^{111}$.

Stalin uważał język za najważniejszy determinant przynależności narodowej, odrzucając rasę i religię jako zbędne w procesie samookreślenia. Niestety sam język był bez znaczenia, jeżeli ludzie posługujący się nim nie zamieszkiwali wspólnego terytorium. Na układ psychiczny składał się charakter narodowy i wspólna kultura społeczeństwa. A pod życiem ekonomicznym krył się wysoko zintegrowany system gospodarczy.

Zgodnie z powyższymi przesłankami, ludność Azji Centralnej nie wpisywała się w stalinowską doktrynę narodowości. Brakowało im odpowiednio zorganizowanego systemu ekonomicznego. A zamieszkujący ogromne terytorium handlarze i rolnicy porozumiewali się różnymi językami. Zatem w miejsce, gdzie brakowało przesłanek konstytuujących narodowość, Stalin postanowił je stworzyć.

Uprzednie wieloetniczne podziały terytorialne Azji Środkowej uznano za nietrafione. $\mathrm{W}$ ich miejsce postanowiono stworzyć nowe terytoria państwowe $\mathrm{z}$ granicami ${ }^{112}$, które będą w większym stopniu korespondować ze stalinowską wizją jednoczenia narodów. Kierując się zasadą jedności etnicznej, podjęto kroki sztucznej kreacji homogenicznych podmiotów państwowych.

$\mathrm{Na}$ terenie nowo powstałych republik wprowadzono z czasem politykę ulokalnienia, w myśl której „narody tytularne były faworyzowane, a ich członkowie mieli uprzywilejowany status w otrzymywaniu świadczeń państwowych w zakresie edukacji, zatrudnienia czy polityki mieszkaniowej"113. Początkowo takie działanie postrzegane było przez władze jako niezbędne w procesie minimalizowania znaczenia Rosjan przebywających w Azji Środkowej i budowania równości wśród narodowości rdzennych ${ }^{114}$. Ponadto, członkowie lokalnych kadr pracowniczych byli zachęcani do przyjmowania wysokich rangą pozycji w regionie. Wykonując swoje obowiązki, mieli dbać o pozytywny wizerunek i popularność władzy sowieckiej ${ }^{115}$. W rzeczywistości była to strategia nakładania na siebie funkcji, albowiem działania wykonywane przez lokalne władze były monitorowane przez ośrodki władzy centralnej w Moskwie, które dbały o jedność polityki na terytorium ZSRR ${ }^{116}$. Przynależność do konkretnej narodowości była nie tyle promowana, ile zinstytucjonalizowana.

111 Stalin J. W., Marksizm a kwestia narodowa, [w:] idem, Dzieła, t. 2, Warszawa 1949, s. 303.

112 Granice państwowe w Azji Centralnej podlegały wielokrotnym korektom aż do roku 1936.

113 Bremmer I., Reassessing Soviet Nationalities Theory, s. 10.

114 Coppieters B., op. cit., s. 23.

115 Martin T., The Affirmative Action Empire: Nations and Nationalism in the Soviet Union, 1923-1939, s. 12.

116 Soucek S., A History of Inner Asia, Cambridge University Press, Cambridge 2000, s. 229. 
Jednostki znajdujące się w granicach danej republiki zmuszone były utożsamiać się $\mathrm{z}$ daną narodowością bez względu na ich z nią związek ${ }^{117}$. Idąc myślą za radzieckimi przesłankami etnofederalizmu członkowie nietytularnych grup etnicznych nie byli obdarzeni żadną formą szczególnej ochrony dziedzictwa kulturowego. W praktyce było to równoznaczne z brakiem przywilejów przysługujących ludności tytularnej, np. autonomii terytorialnej czy prymatu języka narodowego.

Sowieci zachęcali do mieszania się grup etnicznych oraz absorpcji mniejszych grup przez większe, a w miejscach, gdzie nie było przesłanek do jasnej identyfikacji grup etnicznych, takie jednostki sztucznie kreowano ${ }^{118}$, co w bezpośrednim stopniu skutkowało pierwszym podziałem rdzennych narodowości ${ }^{119}$.

W latach 20. władza radziecka zaczęła realizować politykę natywizacji, korenizatsiya, będącej drugim etapem asymilacji. Korienizacja zakładała podział terytorialny wedle kryteriów narodowościowych, troskę o rozwój kultur poszczególnych narodów, wchodzących uprzednio w skład Imperium Rosyjskiego, oraz tworzenie lokalnych partii komunistycznych. Mimo że postrzegano korienizację jako narzędzie propagujące politykę państwa, niektórzy miejscowi aktywiści wykorzystywali ją również w celu propagowania postaw nacjonalistycznych ${ }^{120}$.

Pod koniec lat 20. XX w. Stalin zrezygnował z dotychczas prowadzonej polityki narodowościowej, a tym samym budowy przyjaźni i zrozumienia z lokalnie występującymi religijnymi i etnicznymi mniejszościami ZSRR. Swoje działania usprawiedliwiał przeświadczeniem, iż to właśnie mniejszości narodowe stanowią większe zagrożenie, aniżeli tradycyjny szowinizm radziecki ${ }^{121}$. Takie myślenie podsycała rosnąca w siłę opozycja władzy radzieckiej, przede wszystkim Ruch Basmaczy ${ }^{122}$. Nastąpił czas wielkiego terroru ${ }^{123}$. Pierwsza fala represji przyszła w 1933 roku. Oskarżonych o tendencje nacjonalistyczne obywateli Azji Centralnej zsyłano do gułagów lub zabijano. Zwolnione pozycje kierownicze przekazano Słowianom, a społeczeństwu zasugerowano ignorowanie kwestii narodowościowych ${ }^{124}$. W tamtym

117 Hierarchia terytorialna odegrała również dużą rolę w radzieckiej polityce edukacyjnej. Przede wszystkim w zakresie lingwistycznym. Rozwijano i promowano naukę w narodowych językach największych grup etnicznych. Te mniejsze poddawane były procesom asymilującym $\mathrm{z}$ innymi narodowościami, co automatycznie pozbawiało je możliwości kontynuowania nauki w rodzimym języku. Appleby I., op. cit., s. 852; Shiokawa N., The History of Soviet Language Policy Reconsidered, „Slavic Studies”, Vol. 46 (1999), s. 155-190; Pavlenko A., Multilingualism in Post - Soviet Countries: Language Revival, Language Removal, and Sociolinguistic Theory, „The International Journal of Bilingual Education and Bilingualism", Vol. 11, No. 3-4 (2008), s. 275-314 (280-281).

118 Imomov A., op. cit., s. 112.

119 Bremmer I., Reassessing Soviet Nationalities Theory, s. 9.

120 Rezvani B., Ethno-territorial conflict and coexistence in the Caucasus, Central Asia and Fereydan, s. 75-79.

121 Smith G., Nationalities Policy, [w:] G. Smith [red.], The Nationalities Question in the Post-Soviet States, Longman, London 1996, s. 7.

122 Bremmer I., Reassessing Soviet Nationalities Theory, s. 401.

123 Coppieters B., op. cit., s. 23-24.

124 Soucek S., op. cit., s. 237. 
okresie przynależność do „właściwej” narodowości była niezwykle ważna, albowiem od początku lat 30. odznaczano ją w paszportach wewnętrznych. Pożądany status mógł zatem generować przywileje; nieodpowiedni - asymilacje i deportacje ${ }^{125}$. W 1928 r. rząd radziecki rozpoczął planowe zwalczanie koczownictwa i tradycji religijnych. Represje i podporządkowanie Moskwie trwało wiele dziesiątków lat. Niektórzy intelektualiści przeciwstawiali się postępującej rusyfikacji, skłaniając się ku kulturowemu nacjonalizmowi. Niestety ci, którzy czynnie brali w tym procesie udział, byli brutalnie eliminowani z życia społecznego. W czasie, kiedy Słowianie cieszyli się pełnią praw i wolności, przedstawiciele nietytularnych narodowości zmagali się z doniesieniami o ich nielojalności wobec Związku i idącymi za tymi oskarżeniami konsekwencjami - czystką, aresztowaniem, a nawet egzekucją ${ }^{126}$.

W kolejnych latach - 30. i 40. minionego wieku - Stalin, widząc zagrożenie płynące z rozrastających się i zdobywających coraz większe znaczenie elit mniejszości etnicznych, postanowił poskromić ich siłę, a niekiedy całkowicie ją zlikwidować. W tym celu, wykorzystując doktrynę samookreślenia, podejmowano próby zwerbowania przedstawicieli rodzących się ruchów nacjonalistycznych w szeregi Partii Komunistycznej ${ }^{127}$. Równolegle na całym obszarze ZSRR realizowana była polityka sowietyzacji. Ponadto, chcąc zapobiec potencjalnej solidarności uciśnionych grup etnicznych, kończono proces delimitacji granic sowieckich, nie uwzględniając istniejących wspólnot narodowych ${ }^{128}$.

$\mathrm{W}$ związku z tak prowadzoną polityką, zmienił się również kurs tworzenia tożsamości narodowych w regionie. Jako główny czynnik jednoczący ziemie ZSRR wybrano język rosyjski, marginalizując wszystkie dotychczas promowane dialekty lokalne ${ }^{129}$. W trudnej sytuacji znaleźli się Muzułmanie, których od reszty społeczeństwa izolował język rosyjski obrany za lingua franca regionu ${ }^{130}$. Powrót do cyrylicy w 1940 r. miał na celu dalszą dezorientację narodową obywateli ${ }^{131}$. Kolejnym narzędziem unifikującym narody radzieckiej Rosji była sekularyzacja, zgodnie z którą brutalnie tłumiono przejawy jakiejkolwiek religijnej aktywności ${ }^{132}$.

125 Appleby I., op. cit., s. 852 .

126 By zrównoważyć wykluczające się działania władzy radzieckiej - dążenie do budowy jednolitego państwa wielu narodów i jednoczesne wspieranie polityki paszportowej (narodowej) każdej z republik - zdecydowano się zaostrzyć kontrolę życia społecznego, eliminując tym samym potencjalne zagrożenie władzy w Moskwie i jedności Związku płynące ze strony mniejszościowych grup etnicznych. Jednocześnie próbowano zyskać sympatie wśród mieszkańców głównych grup narodowych, zachęcając i promując ich aktywność w lokalnych organach władzy rządowej. Martin T., The Affirmative Action Empire: Nations and Nationalism in the Soviet Union, 1923-1939, s. 387.

127 Coppieters B., op. cit., s. 18.

128 Soucek S., op. cit., s. 247-248.

129 Fedorenko V., Central Asia: From Ethnic to Civic Nationalism, „Rethink Paper”, March 2012, s. 7-8.

130 Blank S., op. cit., s. 53.

131 Martin T., The Affirmative Action Empire: Nations and Nationalism in the Soviet Union, 1923-1939, s. 26.

132 Fedorenko V., Central Asia: From Ethnic to Civic Nationalism, s. 7-8. 
Region podzielono na pięć republik obdarzonych zmitologizowaną historią i kulturą, których treść miała legitymizować prawo danej ludności do konkretnego terytorium. W tym celu niezbędne było ukazanie historycznie usprawiedliwionej przynależności danej narodowości tytularnej do zamieszkiwanego obszaru. Wprowadzona została idea „autochtonii” (autochtonu, tubylca), zgodnie z którą pochodzenie etniczne danej ludności można było historycznie prześledzić i powiązać $\mathrm{z}$ rdzennymi mieszkańcami danego terytorium ${ }^{133}$, co w konsekwencji miało na celu wzmacniać siłę tożsamości narodowej. Jednak zamiast radzieckiego tygla narodów, $\mathrm{w}$ republikach azjatyckich zaczęły powstawać rosnące w siłę podziały społeczne oparte na wyższości narodów tytularnych i ich bezsprzecznym prawie do danego terytorium. Doprowadziło to do występujących na szeroką skalę praktyk dyskryminacyjnych i rosnących rozbieżności między zamieszkującymi republiki grupami etnicznymi. Wyodrębniały się uprzywilejowane grupy i klany etniczne, które zaczęły walczyć o władzę, zasoby i kontrolę nad państwem. Teoretycznie wszystkie narody ZSRR były sobie równe. W rzeczywistości część z nich była jednak równiejsza, wśród nich Uzbecy. Moskwa umyślnie faworyzowała Uzbekistan ze względu na liczebność jego mieszkańców, poziom rozwoju przemysłowego oraz bogactwo minerałów ${ }^{134}$. Wraz z niepodległością proces ten jedynie się zintensyfikował.

Kolejnym elementem polityki narodowościowej ZSRR były migracje ludności. Nakłaniano, a nierzadko zmuszano, obywateli danego regionu do przeprowadzek i zaludnienia Związku Radzieckiego w całej jego rozciągłości. Celem tych działań była chęć uzyskania jak największej dywersyfikacji etnicznej obszaru. W praktyce było to jednoznaczne $\mathrm{z}$ dominacją Słowian w największych ośrodkach miejskich Azji Centralnej ${ }^{135}$.

\section{Nacjonalizm i komunizm radziecki}

Nacjonalizm w ujęciu Gellnerowskim jest „teorią legitymacji władzy, prawowitości, która w swoich założeniach odstępuje od przecinania granic politycznych granicami etnicznymi" ${ }^{136}$. Naród w tym ujęciu postrzega się jako zbiór wartości kulturowych, którego zasięg pokrywał się z granicami państwa w sensie terytorialnym. Niemniej jednak naród nie był jednoznacznie zobowiązany do podążania i popierania zinstytucjonalizowanej władzy. Występujące w tym wypadku sprzeciwy wobec prowadzonej polityki państwa oraz rodzący się nacjonalizm mogą występować w formie jawnej opozycji całego narodu bądź konkretnej grupy etnicznej. W dłuższej perspektywie prowadzić to może do identyfikacji innych nacji, zamieszkujących dany kraj, jako wrogich. Wynika to z faktu, iż przynależność państwową nie tworzy obywatelstwo,

133 Uyama T., Rethinking the ethnic history of the Kazakhs: Some reflections on historical writing, Chiiki Kenkyu Ronshu [JCAS Review], Vol. 2, No. 1, 1999, s. 104-108.

134 Tabyliasheva A., „The Challenge of Regional Cooperation in Central Asia. Preventing Ethnic Conflict in Ferghana Valley", Peaceworks, No. 28, United States Institute of Peace 1999, s. 4.

135 Fierman W., Identity, Symbolism and the Politics of Language in Central Asia, „Europe - Asia Studies", Vol. 61, No. 7, 2009, s. 1216.

136 Więcej: Gellner E., Nations and Nationalism, Cornell University Press, Ithaca, New York 1983. 
a poczucie jedności narodowej. Na tej płaszczyźnie rodzi się rozdział między zasadami i prawem budującymi państwo a wartościami tworzącymi naród ${ }^{137}$.

Od wieków historia rozdzielała znaczenie państwa z narodem, mimo iż pierwsze niezmiennie rościło sobie prawo do wartości tego drugiego. W trakcie swojej historii nacjonalizm budził skrajne emocje i równie odległe wywoływał skutki. Jednych dzielił, innych łączył. Był symbolem wolności i braterstwa. Stanowił też zagrożenie jako siła niosąca ze sobą wojny i wszędobylskie zniszczenie ${ }^{138}$. Z historycznego punktu widzenia nacjonalizm w ZSRR zawsze stanowił potężną siłę wspierającą rząd i partie polityczne. Występujący w ZSRR nacjonalizm rozumiany był zarówno w kontekście ideologii, jak też strategii politycznej. Obejmował swoją kategorią dążenie do stworzenia niezależnego państwa. A także stanowił przekonanie, że naród jest najważniejszą formą uspołecznienia, a tożsamość narodowa najważniejszym składnikiem tożsamości jednostki. Stanowił jednocześnie nakaz przedkładania solidarności narodowej nad wszelkie inne związki i zobowiązania oraz promowania tego, co narodowe, nad to, co cudzoziemskie. Ideologia polityczna zakładała, że podstawowym zadaniem państwa jest obrona interesów narodowych, a zasięg terytorialny narodu winien odpowiadać obszarom zamieszkanym przez dany naród ${ }^{139}$. Zdecydowana większość narodowców postrzegała idealne państwo jako jednolity naród zamknięty w granicach politycznych, które odzwierciedlają historyczną, wręcz mityczną, przynależność danego społeczeństwa do terytorium. W tym ujęciu państwo było politycznym i geograficznym urzeczywistnieniem narodu.

W mniemaniu Lenina idee nacjonalistyczne znajdowały się w relacji podrzędnej do ideałów komunistycznych. Niemniej jednak, jako zwolennik antyimperializmu, prawdopodobnie szczerze wierzył w nacjonalizm jako narzędzie wyzwolenia narodów. Duże znaczenie w procesie kreowania postaw nacjonalistycznych miała w tamtym czasie przestrzeń międzynarodowa. Tuż po I wojnie światowej, kiedy na ruinach Imperium Otomańskiego budowano nowe państwa, prawo do samostanowienia narodów nabierało mocy. Wspierając owo prawo, Lenin żywił wielką nadzieję na stworzenie Związku Radzieckiego, który będzie nie tylko przykładem jedynej w swoim rodzaju jednostki polityczno-terytorialnej, ale przede wszystkim liczył na to, że z czasem proces ten stanie się platformą, za pomocą której zbliży obywateli do prawdziwego komunizmu. Z perspektywy przyszłości prawo do samostanowienia postrzegano jako kolejny krok w procesie socjalnego i społecznego rozwoju ${ }^{140}$. Jednym z efektów wdrażania prawa do samostanowienia narodów stało się upolitycznienie narodowości w Związku Radzieckim. Populacja ZSRR była podzielona na oficjalnie rozpoznawalne i uznawalne grupy etniczne. Kategorie, do których przypisywano poszczególne narody, z czasem ulegały zmianom nomenklaturowym i pozycyjnym

137 Fabri M., Demographic Processes, Nationalism and Ethnic Conflicts, [w:] A. G. Vishnevsky [red.] Encyclopedia of Life Support Systems, Population and Development: Challenges and Opportunities, Vol. 1, 2009, s. 277-278.

138 Więcej: Nairn T., Faces of Nationalism: Janus Revisited, Verso, New York 1997.

139 Breuilly J., Nationalism and the State, Manchester University Press, Manchester 1982, s. 3.

140 Slezkine Y., op. cit., s. 417-421. 
w tym sensie, że mniej liczebne grupy etniczne wpisywano w kategorie narodowe grup etnicznych, z którymi je asymilowano lub z którymi były najbliżej spowinowacone $^{141}$. Narodowość etniczna była zatem „wyodrębnioną, obligatoryjną i askryptywną kategorią prawną, kluczowym elementem statusu prawnego jednostki"142.

W przeciwieństwie do austromarksizmu, którego przedstawiciele kładli duży nacisk na kwestię autonomii kulturalno-narodowej postrzeganej jako środek mający zaradzić problemom narodowościowym Austro-Węgier, bolszewicy zdecydowali się na federalną formę Związku, która miała wspomóc ich działania w realizacji prawa do samostanowienia narodów. Nie było to jednak jednoznaczne z brakiem kulturowej samorządności ${ }^{143}$, wręcz przeciwnie. Pewne formy terytorialnie rozpierzchniętej autonomii kulturowej były obecne przez cały okres trwania Związku Radzieckiego. Choć nie w każdym przypadku stanowiło to regułę. W świetle etnofederalnego systemu ZSRR, prawa i przywileje narodowo-kulturowe przypisywano tytularnym jednostkom terytorialnym, kierując instrumenty polityki asymilacyjnej w stronę nietytularnych grup etnicznych ${ }^{144}$. Rozwój nacjonalizmu terytorialnego wśród narodu tytularnego prowadził do prób ustalenia hegemonii w granicach terytorium postrzeganego za ojczyznę. Często przejawiało się to w przyznawaniu przywilejów przedstawicielom dominującej grupy etnicznej, preferencyjnym traktowaniu i zachwianiu równoprawnej egzekucji praw, generując tym samym dysproporcje w traktowaniu wszystkich obywateli danego państwa. Najczęstszą odpowiedzią przedstawicieli mniejszości etnicznych na tego rodzaju praktyki był tzw. nacjonalizm reaktywny ${ }^{145}$.

Lenin wraz z bolszewikami podeszli pragmatycznie do realizacji prawa narodów do samostanowienia. Zdając sobie sprawę z tymczasowego braku możliwości i wystarczającej siły w spójnym rządzeniu całym terytorium Związku Radzieckiego, zdecydowali część władzy przekazać w ręce lokalnych, mniej lub bardziej znacjonalizowanych członków grup etnicznych. W następstwie podjętych działań szeregi

141 Hirsch F., The Soviet Union as a Work-In-Progress: Ethnographers and he Category Nationality in the 1926, 1937 and 1939 Censuses, „Slavic Review”, Vol. 56, No. 2 (1997), s. 252-278.

142 Brubaker R., Nationhood and the National Question in the Soviet Union and Post - Soviet Eurasia: An Institutionalist Account, „Theory and Society”, Vol. 23, No. 1 (1994), s. 53.

143 Status ZSRR zbudowany był na fundamencie autonomii kulturowej podmiotów federacji, a nie ich suwerenności. Z kolei federacyjny kształt Związku Radzieckiego usprawiedliwiało rozłożenie przestrzenne znacznej liczby mniejszości etnicznych. W czasach carskich mniejszości narodowe skoncentrowane były na obrzeżach Imperium, rzadko kiedy zamieszkując większe ośrodki miejskie. Ponadto, z tak rozległym obszarem państwowym, nierozwiniętymi szlakami komunikacyjnymi i transportowymi, możliwość stworzenia kulturowej autonomii nieterytorialnej byłaby nieracjonalnym obciążeniem systemu, o ile w ogóle byłaby możliwa. Kolossov V., Nationalism versus „World Society”: A view from Russia, [w:] P. J. Taylor [red.], Political Geography of the Twentieth Century: A Global Analysis, John Wiley \& Sons, Chichester \& New York 1995, s. 242.

144 Bremmer I., Post-Soviet Nationalities Theory: Past, Present, and Future, [w:] I. Bremmer, R. Taras [red.], New States, New Politics: Building the Post-Soviet Nations, Cambridge University Press, Cambridge 1997, s. 14.

145 Kemp W., Nationalism and Communism in Eastern Europe and the Soviet Union: A basic contradiction?, Macmillan, London 1999, s. 189. 
partii zaczęli zasilać przedstawiciele miejscowych elit, wśród których bolszewicy szukali poparcia swojej polityki. Nacjonalizm etniczny w ZSRR stał się czynnikiem ideologicznym i politycznym pod koniec lat 50. XX w., kiedy Chruszczow zainicjował politykę destalinizacji.

Wybitny socjolog, Ernest Gellner, analizując przestrzeń państwową ZSRR, uznał radziecki komunizm za narzędzie wykorzystywane $\mathrm{w}$ walce $\mathrm{z}$ rosnącym $\mathrm{w}$ siłę nacjonalizmem regionalnym; instrumentem, które Moskwa wykorzystywała do czasu uzyskania pełni władzy i kontroli nad danym państwem ${ }^{146}$. W podobnym tonie wypowiadał się Eric Hobsbawm, który twierdził, że jedynie strach i przymus, który niósł ze sobą komunizm radziecki utrzymywały ZSRR w jedności, pomagając władzy w procesie zapobiegania eskalacji napięć etnicznych i społecznych. Hobsbawm uważał również, że późniejsza dezintegracja narodowościowa ZSRR była konsekwencją rozpadu władzy sowieckiej, aniżeli jego przyczyną ${ }^{147}$. Dahl twierdził z kolei, że ceną za poliarchię $\mathrm{w}$ wielokulturowym społeczeństwie może być właśnie rozpad państwa, a kosztem jedności terytorialnej takiego społeczeństwie jest zazwyczaj hegemoniczny reżim ${ }^{148}$. Wywodzące się z niego tzw. poczucie tożsamości narodowej stało się z biegiem lat poważną siłą w Azji Centralnej. Szczególnie w dobie niepodległości, kiedy nacjonalizm zaczął być wykorzystywany przez liderów republik jako narzędzie, które sprawnie implementowane pozwalało zdystansować się od reżimu radzieckiego. W późniejszym czasie nacjonalizm miał uprawomocnić ich władzę oraz zdobyć bezsprzeczną kontrolę nad nowo powstałymi państwami.

Obecnie grono ekspertów z zakresu nauk politycznych i filozofii politycznej twierdzi, iż etnicznie i narodowo podzielone społeczeństwa można ustabilizować, wykorzystując $\mathrm{w}$ tym celu adekwatne do sytuacji strategie polityczne. B. O’Leary przeanalizował szereg możliwych rozwiązań, którymi w polityce mogą posiłkować się państwa wielonarodowe, by w ostateczności wyróżnić dwie najważniejsze grupy instrumentów. Pierwsza z nich odnosi się do podejścia instytucjonalnego skupionego na ideach konstytucjonalno-ustrojowych i preferencjach dla form konsocjonalizmu, zasad federalizmu lub porozumień o autonomii; druga - do praw grupowo zróżnicowanych ${ }^{149}$. Bardzo często zaleca się federalizm jako strukturalny i instytucjonalny mechanizm stabilizujący etnicznie zróżnicowane państwa. Z perspektywy ZSRR taka kombinacja kontroli i parafederalnych ograniczeń zdołała w pewnym stopniu poradzić sobie $\mathrm{z}$ występującymi $\mathrm{w}$ federacji antagonizmami o podłożu historycznym i narodowościowym.

Jak wskazał Ian Lustick, te ograniczenie i kontrola są niezwykle efektywnymi środkami regulacji napięć w mocno podzielonych społeczeństwach ${ }^{150}$. Funkcjonujący

146 Gellner E., Nationalism, Weidenfeld \& Nicholson, Londyn 1997, s. 86.

147 Hobsbawm E., Nations and Nationalism Since 1780: Programme, Myth and Reality, Cambridge University Press, Cambridge 1990, s. 168.

148 Dahl R., Polyarchy: Participation and Opposition, Yale University Press, New Haven 1971, s. 121.

149 O'Leary B., Nationalism and Ethnicity: Research Agendas on Theories of Their Sources and Their Regulation, [w:] D. Chirot, M. E. P. Saligman [red.], Ethnopolitical Warfare: Causes, Consequences and Possible Solutions, American Psychological Association, Washington 2001, s. 44.

150 Lustick I., Stability in Deeply Divided Societies, „World Politics”, Vol. 31, No. 3, 1979, s. 325-344. 
w ZSRR system kontroli w sposób cyniczny manipulował procesami narodowościowymi, używając w tym celu pseudo-federalnych mechanizmów instytucjonalnych, np. obowiązującego jedynie w teorii prawa do secesji republik związkowych czy praw i przywilejów kulturowych. Tego typu działania pozwoliły władzy w Moskwie zapewnić względny spokój wewnątrz granic Związku oraz wykreowały na arenie międzynarodowej wizerunek modelowego państwa wielonarodowego; wyobrażenie, które rozwijało się przez większość XX wieku - od Lenina po Breżniewa.

\section{Islam w sowieckiej Azji Centralnej}

W całej swojej historii w regionie wyznawcy islamu przeciwstawiani byli innym kulturom, rządom i strategiom. Mongołowie, Chrześcijanie, rosyjscy marksiści wymieniając najważniejszych - podejmowali próby przejęcia regionu, stosując w tym celu masowe zsyłki ludności, nawracanie religijne, biologiczną i kulturową asymilację oraz wiele innych. Odzew przybierał zróżnicowane formy. Od zbrojnego oporu strzegącego miejscowej kultury i terytorium, przez wzrost znaczenia radykalnego islamu do podejmowanej współpracy z „niewiernymi” ${ }^{151}$. W epoce rządów radzieckich muzułmańscy teologowie skłaniali się ku trzeciej formie działania, kierując się liberalnym w postulatach dżadydyzmem ${ }^{152}$.

Władza radziecka odbierała Islam jako zagrożenie kreowanego spokoju i socjalistycznej równości w społeczeństwie. Zgodnie z doktryną ateistyczną ZSRR Islam, jak też każda inna religia, był kwalifikowany jako przesąd, wytwór wyobraźni mający swoje korzenie w głębokiej przeszłości. Ateistyczna propaganda wskazywała na brak historycznie usprawiedliwionych więzi kulturowo-społecznych Islamu z zamieszkującą region ludnością. Podnoszono również kwestię pochodzenia tejże religii. Argumentowano w tym wypadku, iż islam jest religią zagraniczną wprowadzoną do Azji Centralnej przez arabskich, perskich i tureckich najeźdźców. Nie ma w związku z tym żadnej racjonalnej przesłanki, by podtrzymywać pogląd stanowiący, że islam jest religią narodową lub/i religią wywodzącą się z Azji Środkowej. Co więcej, twierdzono, że islam generuje postawy dyskryminacyjne i ksenofobiczne. Stając tym samym w opozycji do założeń Partii Komunistycznej, nie ma dla niego miejsca w opartej na jedności i równości socjalistycznej przestrzeni Związku Radzieckiego ${ }^{153}$.

Islam zawsze był jedną z sił determinujących tożsamość religijną i kulturową Azji Centralnej. Ponadto, był czynnikiem regulującym wewnętrzne stosunki i w pewnym sensie zewnętrzną orientację na świat, nawet będąc poddanym władzy radzieckiej.

151 Benningsen A., Wimbush S. E., Muslims of the Soviet Empire, C. Hurst \& Company, London 1985, s. 62.

152 Muzułmańska ludność Azji Centralnej pokładała nadzieję w dżadydyzmie, albowiem jako liberalny odłam islamu optował za antykolonializmem, żądając większej autonomii dla społeczeństwa Azji Centralnej. Więcej: Abdullayev A., Islamic Tradition of Raising Children and its Applicability in Uzbekistan, „Muslims of Soviet East”, 1980/1, (tu: 58); Khalid A., op. cit., s. 296; Rashid A., Dżihad. Narodziny wojującego islamu w Azji Środkowej, Wydawnictwo Akademickie Dialog, Warszawa 2003, s. 47.

153 Bennigsen A., Islam and Political Power in the USSR, [w:] G. Benavides, M. W. Daly [red.], Religion and Political Power, SUNY Press, Albany 1989, s. 75. 
Islamizacja Azji Centralnej rozpoczęła się w drugiej połowie VII w. wraz z wkroczeniem do regionu wojsk arabskich. Od tamtego czasu Arabowie zapoznawali z nową religią osady lokalnych farmerów i handlarzy. Ze względu na przedislamskie tradycje regionu, kulturę ludów tamtejszych mieszkańców oraz geopolityczną sytuacją, zaznajamianie rdzennych mieszkańców z religią muzułmańską było procesem nierównym i wydłużonym w czasie ${ }^{154}$. Islam rozwijał się na dwóch płaszczyznach geograficznych równolegle - w Transoksanii ${ }^{155}$, której obywatele charakteryzowali się osiadłym trybem życia, i w nomadycznym Turkiestanie ${ }^{156}$. Buchara, Samarkanda i Chiwa wyrastały w tym czasie na główne ośrodki kultury i religii muzułmańskiej w całym ówczesnym świecie Islamu.

Rozległe stepy Turkiestanu zamieszkiwane przez wędrowne ludy były mniej przyjazne zarówno w wypadku rozwoju religii, jak i samego procesu nawracania lokalnej społeczności na islam. Praktyka religii islamskiej w szeregach społeczeństw koczowniczych nieprzerwanie przeplatała się z przedislamskimi tradycjami pogańskimi oraz adatami - muzułmańskimi prawami zwyczajowymi powszechnie obowiązującymi na Stepie. Mimo niesprzyjających warunków, w X w. Turkmeni zostali wciągnięci w świat Islamu. Pod koniec XIX w. na islam sunnicki nawrócono również Kazachów i Kirgizów ${ }^{157}$.

Niektórzy dżadydzi walczyli w Rewolucji po stronie Białych, chociaż wielu z nich zgadzało się z bolszewikami na poziomie ideologicznym. Ci, którzy wstąpili do partii komunistycznej, odegrali dużą rolę w tworzeniu jej lokalnych komórek w Azji Środkowej. Mimo rozwijającej się współpracy, wielu z nich zostało uznanych za burżuazyjnych reformatorów bardziej oddanych religii i nacjonalizmowi, aniżeli komunizmowi. Na tych właśnie czekały represje ${ }^{158}$. Dzięki współpracy z partiami lewicowymi w czasie rewolucji październikowej ruch istniał do lat 30. XX wieku ${ }^{159}$.

W czasach kolonizacji carskiej administracja wprowadziła istotny podział ludów koczowniczych i osiadłych na podstawie roli, jaką wśród nich odgrywał Islam ${ }^{160}$.

154 Niezwykle istotnym czynnikiem w początkowych stadiach adaptacji Islamu w regionie był osiadły tryb życia przodków współczesnych mieszkańców Azji Centralnej - Tadżyków i Uzbeków. Wynikało to przede wszystkim z tego, iż stałe miejsce zamieszkania służyło praktyce religijnej - prawa i obowiązki Islamu wymagają rozwiniętej infrastruktury miejskiej. Zapaśnik S., „Walczący Islam” w Azji Centralnej. Problem społecznej genezy zjawiska, Fundacja na rzecz Nauki Polskiej, Wydawnictwo Uniwersytetu Wrocławskiego Sp. z o.o., Wrocław 2006, s. 21-25.

155 Nazwa części Azji Środkowej, odpowiadającej w przybliżeniu dzisiejszemu Uzbekistanowi, Tadżykistanowi oraz południowo-zachodniemu Kazachstanowi.

156 Część Azji Środkowej leżąca pomiędzy Syberią na północy a Tybetem, Indiami i Afganistanem na południu, oraz Morzem Kaspijskim na zachodzie i wschodnią Mongolią oraz pustynią Gobi na wschodzie.

157 Sagdeev R., Central Asia and Islam: An Overview, [w:] R. Sagdeev, S. Eisenhower [red.], Islam and Central Asia: An Enduring Legacy or an Evolving Threat?, Center for Political and Strategic Studies, Washington, D.C. 2000, s. 8.

158 Rashid A., op. cit., s. 47.

159 Landowski Z., Islam. Nurty, odłamy, sekty, Książka i Wiedza, Warszawa 2008, s. 81.

$160 \mathrm{~W}$ społeczeństwie nomadycznym Imperium Rosyjskie wspierało procesy rusyfikacji oraz rządy i praktykę miejscowych praw zwyczajowych. Z drugiej strony ludność o osiadłym trybie 
Przez wieki wśród mieszkańców Azji Centralnej panowała, wyrosła na gruncie prowadzonego trybu życia, rywalizacja dotycząca poziomu religijności. Uzbecy uważali się za lepszych od Kazachów, a Tadżycy postrzegali siebie jako jedynych i prawdziwych Muzułmanów ${ }^{161}$. Turkmenów, Kazachów i Kirgizów uważano za tzw. symbolicznych Muzułmanów, jako że nigdy poważnie nie zgłębiali praw i zakazów nakładanych przez religię ${ }^{162}$. Islam odgrywał tam bardziej powierzchowną i zróżnicowaną rolę niż wśród ludów o osiadłym trybie życia zamieszkujących Uzbekistan i Tadżykistan. Polityka carska, a następnie radziecka, tylko pogłębiła te różnice. Niemniej jednak, wielu muzułmanów zamieszkujących Azję Centralną rozpatrywało podboje rosyjskie XIX w. właśnie w kontekście religijnym. Według Muftiego Taszkientu, Z. Babakhan, islam w czasach rosyjskiego Imperium był religią ludzi dyskryminowanych i upokarzanych postępującą nierównością społeczną, ale przede wszystkim był religią ludzi zmagających się z codziennymi prześladowaniami narodowymi wyrosłymi na gruncie wiary. Dlatego też władza radziecka w oczach tego teologa pełniła rolę wybawcy, a nie oprawcy Muzułmanów w Azji Centralnej. W czasach Rewolucji Sowieci widzieli w Muzułmanach swoich sprzymierzeńców w wojnie z imperializmem i kolonializmem. Polegali na ich zastępach w walce o władzę. Czynili zatem kroki mające zyskać przychylność Muzułmanów. Nie później jak pod koniec 1917 r. rząd radziecki zadeklarował, iż:

Od tej pory wasza wiara i obyczaje, wasze narodowe i kulturalne instytucje będą wolne i nienaruszalne. Macie do tego prawo. Bądźcie świadomi, że na straży waszych praw stoi rewolucja i jej organy władzy ${ }^{163}$.

Pierwszy dekret regulujący sprawy religii O rozdziale państwa i szkoły od Kościoła został wydany 23 stycznia 1918 roku. Jego postanowienia przyznawały wszystkim obywatelom radzieckiej Rosji pozorną wolność wyznania oraz uznawały religię jako osobistą sprawę każdego człowieka ${ }^{164}$. Proklamując równość wszystkich religii, państwo zakazywało tworzenia regulacji prawnych, które mogłyby powstrzymywać egzekucję lub ograniczać prawo obywateli do wolności wyznania. W rzeczywistości było to jednoznaczne z przyznaniem wszystkim obywatelom także prawa do anty-

życia, głęboko związana z Islamem, niezmiennie podlegała prawom Szariatu. W rezultacie podziału charakterystyczne dla obu regionów - Transoksanii i Turkiestanu - płaszczyzny, instytucje edukacyjne i kulturowe związane z religią pozostały niewzruszone. Khalid A., Islam after Communism: Religion and Politics in Central Asia, University of California Press, Berkeley 2007, s. 33, 38.

161 Roy O., Islam in Tajikistan, „Occasional Paper”, No. 1, New York: The Project on Open Society in Central Eurasia, July 1996, s. 2.

162 Klyashtorny S. G., Sultanov T. I, Kazakhstan: Annals of Three Millennia, Almaty 1992, s. 150; Ekiert M., Islam w Azji Środkowej, „Za Uralem”, nr 4/1996.

163 Babakhan Z., Islam and Muslims in the Land of Soviets, tr. R. Dixon, Progress Publishers, Moscow 1980, s. 44.

164 Erşahin S., The Official Interpretation of Islam under the Soviet Regime under the Soviet regime A base for understanding of contemporary Central Asian Islam, „Journal of Religious Culture”, No. 77 (2005), Frankfurt am Main Johann-Wolfgang-Goethe-University, s. 6. 
religijnej propagandy ${ }^{165}$. Rozdział kościoła od państwa sprawił, że kult religijny został przesunięty na peryferie życia społecznego. A sam zapis dekretowy stanowił podstawę rosnącej w siłę walki państwa radzieckiego $\mathrm{z}$ wiarą.

Islam w Azji Centralnej był zasadniczym elementem w procesie samoidentyfikacji narodów. Jako główna religia regionu stanowił zatem niebezpieczeństwo dla polityki ZSRR i rozwoju komunizmu. Na przełomie XIX i XX w. ówczesne tożsamości ludów Azji Środkowej zostały przekształcone i przekonfigurowane. Niektórzy przedstawiciele rdzennych grup etnicznych zaczęli myśleć o swojej tożsamości w kategoriach nacjonalistycznych. Inni zwrócili się w stronę pantureckiej ideologii i tożsamości narodowej, która często łączyła się z rosnącym w siłę upolitycznionym islamem. Panturkizm i panislamizm rozwijały się równolegle jako część ruchu dżadydów - nurtu religijnego o podłożu intelektualnym ${ }^{166}$. W latach 1905-1917 ruch ten zyskał zwolenników w Azji Środkowej, szybko rozprzestrzeniając się na jej terenach. W 1917 r. dżadydom udało się na chwilę objąć władzę w Chanacie Chiwy ${ }^{167}$. Już w trakcie delimitacji granic zauważalna była jawna obawa bolszewików o rozwój idei panislamizmu i panturkizmu, których wzrost znaczenia wśród lokalnej ludności mógłby w bezpośrednim stopniu zagrażać budowie wielkiego i jednolitego państwa sowieckiego. W związku z rosnącym niepokojem o podłożu religijnym, postanowiono zadbać o minimalizację relacji między narodowościami, dzieląc je granicami pogłębiającymi obecne podziały w społeczeństwie ${ }^{168}$.

Ponadto, kierowana przez bolszewików w latach 20. kampania antyreligijna podważała znaczenie islamu jako religii i formy organizacji społecznej. W latach 30. zniesiono pismo arabskie, które zastąpiono alfabetem łacińskim, co w konsekwencji uniemożliwiło Muzułmanom w Azji Centralnej czytanie świętej księgi Koranu oraz dzieł historycznych. Muzułmańskie ośrodki kultury, szkoły i meczety zmieniały swoje przeznaczenie, stając się pomnikami komunizmu i ateizmu ${ }^{169}$ - salami kinowymi, klubami, garażami i innymi budynkami użytku publicznego. Od $1935 \mathrm{r}$. duchowni regularnie byli poddawani represjom, a muzułmański system prawny, w tym sądy religijne, zostały zniesione. Jednocześnie zabroniono praktyki dwóch z pięciu podstawowych przykazań religijnych wyznawców islamu, tj. pielgrzymki do Mekki i zakatu ${ }^{170}$. Ostrej krytyce poddany został również Ramadan ${ }^{171}$. Jednak wszystkie rządowe działania były niewystarczające, by trwale pozbyć się głęboko zakorzenionej wiary nierozerwalnie związanej z panującymi od wieków zwycza-

165 Babakhan Z., op. cit., s. 45.

166 Historia myśli politycznej uznaje dżadydyzm za jeden z największych świeckich ruchów reformatorskich, jakie powstały w świecie muzułmańskim w epoce nowożytnej.

167 Wójcik J., Ruch basmaczy w radzieckiej Azji Środkowej 1918-1933, Fundacja Studiów Międzynarodowych, Warszawa 2008, s. 33-34.

168 Blank S., op. cit., s. 54.

169 Soucek S., op. cit., s. 277-278.

170 Podkreślano, iż w państwie, w którym panowała szeroko pojęta równość obywateli, w którym nie było biednych ani bogatych, nie istniały warunki do wypełniania zakatu.

171 Bennigsen A., op. cit., s. 71-72. 
jami, rytuałami i tożsamością społeczną. W międzywojennej rzeczywistości ZSRR religię muzułmańską praktykowano w podziemiu ${ }^{172}$.

Związek Socjalistycznych Republik Radzieckich był państwem świeckim, w którym religia pozostawała sprawą osobistą każdego obywatela. Oficjalnie nie spotykano się z dyskryminacją na tle religijnym. W teorii wyznawcy wszystkich religii byli w Związku Radzieckim równi wobec prawa i obowiązków, jakie to prawo nakładało. Radziecka polityka religijna była jednolita. Jej postanowienia miały zastosowanie do każdego wyznania. Wyraz temu poglądowi dawał zapis art. 124 Konstytucji ZSRR z 1936 r.:

Art. 124. W celu zapewnienia obywatelom wolności sumienia kościół w ZSRR oddzielony jest od państwa, a szkoła od kościoła. Wolność uprawiania kultów religijnych oraz wolność propagandy antyreligijnej przysługuje wszystkim obywatelom ${ }^{173}$.

Z powyższego zapisu zarysowuje się obraz Związku Radzieckiego jako państwa, które przychyla się ku ateizmowi. Szkoły nie realizowały programu nauczania religii, a wolność praktyk religijnych ograniczała się jedynie do obserwacji obrządków i ceremonii odprawianych w ośrodkach modlitewnych, wobec czego wszelka aktywność poza murami meczetów była nielegalna. Wygłaszanie kazań, nauczanie i przewodniczenie ceremoniom o charakterze religijnym były wykroczeniem kryminalnym. Stowarzyszenia religijne nie miały podstawy prawnej do istnienia i traktowane były jako ośrodki konspiracyjne. Ponadto, organizacje podejrzane o głoszenie antysowieckich haseł były w myśl litery prawa traktowane jako podmioty przestępcze ${ }^{174}$. Azja Centralna była odizolowana od reszty świata islamskiego, a co za tym idzie od postępów w sferze religii. System komunistyczny czynił wszelkie kroki zapobiegające modernizacji religii Islamu. Intelektualiści muzułmańscy byli represjonowani, a bardziej postępowi liderzy religijni byli uciszani lub likwidowani ${ }^{175}$.

Pewne złagodzenie polityki antyreligijnej nastąpiło w trakcie II wojny światowej. Przede wszystkim po 1941 r., kiedy Niemcy wkroczyli na terytorium Rosji. Moskwa uzupełniała w tym czasie szeregi swojej armii i ponownie liczyła na wsparcie ludności muzułmańskiej. Uznano wówczas, że religia muzułmańska nie stanowi już bezpośredniego zagrożenia. Co było ważnym komunikatem z perspektywy propagandy - ocieplenie stosunków zyskałoby aprobatę sojuszników i Muzułmanów za granicą. Poprawa wizerunku władzy radzieckiej pomogłaby również zrównoważyć lata prześladowań. Chcąc zatem nieco skorygować wzajemne relacje, władze centralne postanowiły ponownie otworzyć, ale nadal monitorować, madrasy w Bucharze i Taszkiencie ${ }^{176}$. Ponadto, zdecydowano się zinstytucjonalizować religię Islamu,

172 Bohr A., Turkmenistan and the Turkmen, s. 387-388.

173 Konstytucja ZSRR z 1936 r., Bucknell University, strona internetowa http://www.departments.bucknell.edu/russian/const/1936toc.html stan z dnia 01-08-2014 r.

174 Bennigsen A., op. cit., s. 71.

175 Sultangalieva A., Religion in Transition, „Central Asia Monitor”, No. 6, June 1996, s. 28.

176 Bohr A., Turkmenistan and the Turkmen, s. 388. 
nadając jej na poziomie państwa oficjalną strukturę administracyjną w postaci czterech Duchowych Zarządów Muzułmanów ${ }^{177}$. Miało to przede wszystkim służyć Moskwie w nadzorze nie tylko zachowania wiernych, ale również życia politycznego skupionego wokół ośrodków wiary. Geograficzny podział Islamu, kreujący scentralizowane muzułmańskie okręgi administracyjne, miał również na celu kontrolę wzrostu znaczenia radykalnie konserwatywnych odłamów religii i szerzenia haseł antyradzieckich ${ }^{178}$. Tuż po wojnie, liczono na dalszą poprawę stosunków z narodem muzułmańskim, zezwalając na legalne działanie placówek islamskich, takich jak szkoły i meczety, ale nie angażując się w formalne nadawanie prawa do wolności wyznania $^{179}$. Stan ten nie trwał jednak długo. Po śmierci Stalina w 1953 r. surowy kurs antyreligijny przeplatany epizodami ocieplenia wzajemnych stosunków powrócił i trwał aż do pieriestrojki, kiedy w 1990 r. przyjęto Ustawę o Wolności Wyznania i Organizacji Religijnych ${ }^{180}$.

Po utworzeniu Administracji dla Muzulmanów, radykalna część zgromadzenia ulemy zdystansowała się od duchowieństwa kontrolowanego przez reżim radziecki i zaczęła nawoływać do reislamizacji, przede wszystkim, Uzbekistanu i Tadżykistanu. W okresie breżniewskim część duchowieństwa rozpoczęła nauczanie wybranych grup studentów w podziemnych kręgach religijnych ${ }^{181}$. W późniejszych czasach grupy te zradykalizowały swoje nauki, ewoluując $\mathrm{w}$ formie do radykalnego ruchu religijnego - Wahabizmu. ${ }^{182}$. Równolegle do działań podejmowanych przez ulemów, w latach 50. i 60. toczył się proces odbudowy tradycyjnego islamu, przede wszystkim w Kotlinie Fergańskiej. Szczególnie było to widoczne u progu rozpadu ZSRR. W tym samym czasie zaczął przybierać na sile ekstremizm muzułmański w Azji Środkowej.

W 1959 r. Chruszczow rozpoczął drugą kampanię antyislamską. Ta krótka, aczkolwiek brutalna akcja zakończyła się w 1964 roku. W tym czasie zamknięto większość meczetów. Ich liczba utrzymywała się na stałym poziomie do 1978 r., kiedy skromne odrodzenie islamu zostało zapoczątkowane otwarciem nowych świątyń. W 1976 r. w Azji Centralnej i Kazachstanie działały 143 meczety. Od czasów II wojny światowej zdecydowana ich większość zlokalizowana była w ośrodkach miejskich, gdzie występowała odpowiednia liczba zarejestrowanych kleryków. Obszary wiejskie, niegdyś centrum życia religijnego, stały się miejscem praktyk nieoficjalnego islamu reprezentowanego przez bractwa sufickie lub niezarejestrowanych mułłów ${ }^{183}$.

177 Bennigsen A., op. cit., s. 72-77.

178 Benningsen A., Wimbush S. E., op. cit., s. 14.

179 Bohr A., Turkmenistan and the Turkmen, s. 388.

180 Bennigsen A., op. cit., s. 72-76.

181 Khalid A., Islam after Communism..., s. 114.

182 Za czasów ZSRR środkowoazjatyccy muzułmanie traktowali wiarę jako punkt odniesienia kulturowego, natomiast radykaliści islamscy (np. wahabici) w innych częściach świata postrzegali ją w kategoriach ideologicznych.

183 Bennigsen A., Lemercier-Quelquejay Ch., 'Official' Islam in the Soviet Union, „Religion in Communist Lands", Vol. 7, Issue 3, Keston College, Keston 1979, s. 151-153. 
Mapa 4. Rozłożenie populacji muzułmańskiej w ZSRR w 1979 r.

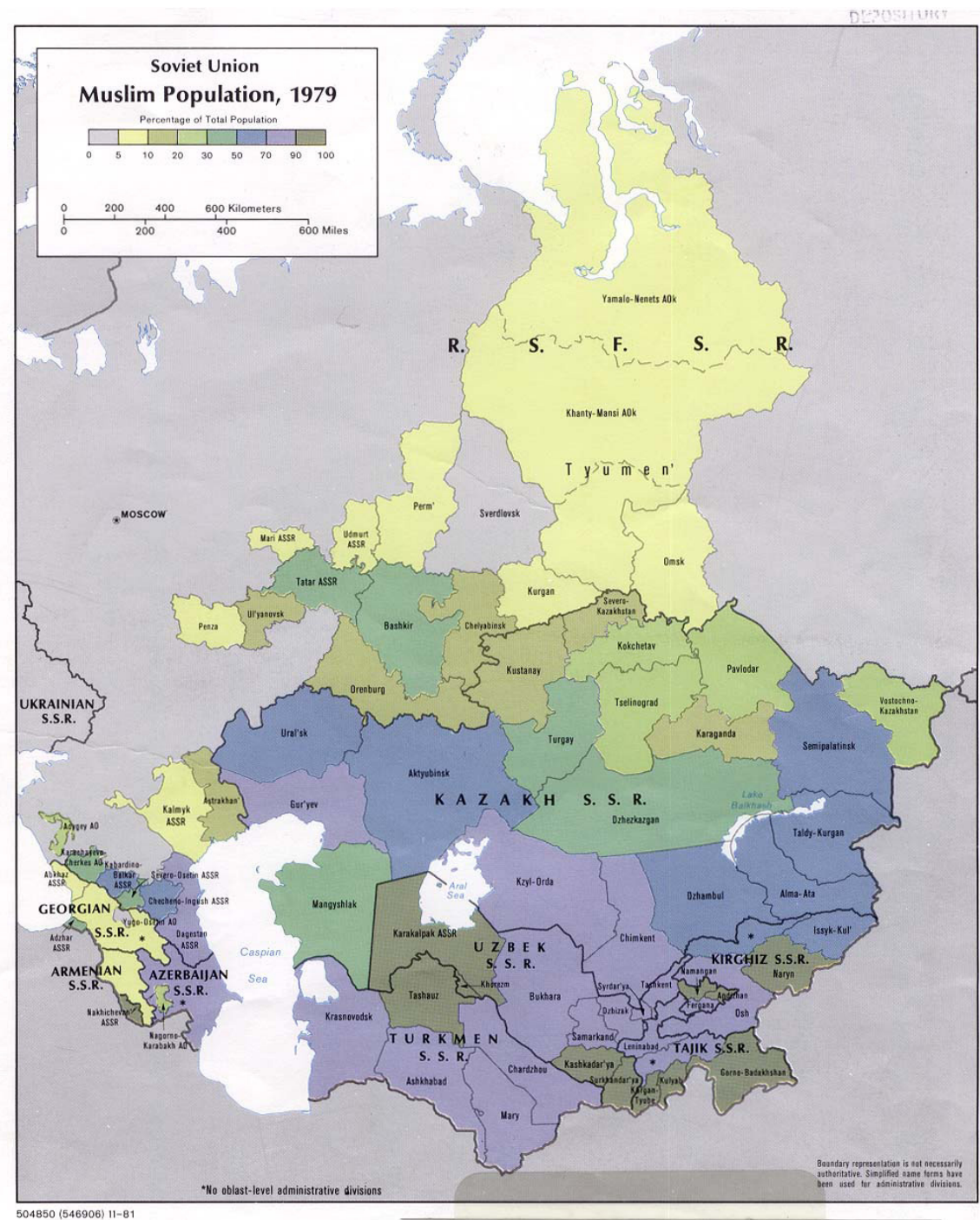

Źródło: University of Texas Libraries, http://www.lib.utexas.edu/maps/commonwealth/soviet_ union_mus_pop_1979.jpg stan z dnia 23-06-2014.

W 1969 r. Leonid Breżniew, ówczesny przywódca KPZR, zainicjował nowy kierunek w relacjach radziecko-islamskich, wskazując Azję Centralną za przykład polityki równowagi we wszystkich państwach muzułmańskich. Pod koniec lat 70. radzieccy przywódcy muzułmańscy realizowali liberalny program odrodzenia religijnego. Zarejestrowani muzułmańscy przywódcy duchowi nie krytykowali polityki Partii Komunistycznej, a tym bardziej nie potępiali marksizmu. Jednocześnie zdecydowa- 
nie odżegnywali się od równolegle działającego konserwatywnego odłamu islamu, którego skrajne postulaty zapuszczały korzenie w umysłach zniewolonej społeczności. Na tyle, na ile było to możliwe przedstawiciele „oficjalnie” działającego islamu współpracowali z komunistycznym aparatem władzy. Zwracając przy tym uwagę na płynące z tej współpracy korzyści oraz zdolności adaptacyjne Muzułmanów do warunków radzieckich, specjaliści od sowieckiej propagandy niejednokrotnie ostrzegali, że umiarkowani Muzułmanie są równie groźni jak konserwatyści ${ }^{184}$.

Kiedy rząd radziecki złagodził politykę religijną, islam powrócił do życia społecznego w Azji Środkowej. Jednak przywrócenie jego siły oddziaływania było tak samo nierówno rozłożone pod względem terytorialnym, jak i jego rozwój w VII i VIII wieku. Tradycyjnymi ośrodkami kultury i religii muzułmańskiej zostały w tym czasie Uzbekistan ${ }^{185}$ i Tadżykistan. W późniejszym okresie również południowe tereny Kazachstanu i Kirgistanu stały się centrum rewitalizowanej siły islamu ${ }^{186}$. W Turkmenistanie aktywność religijna pozostała wyciszona ${ }^{187}$.

\section{Post-stalinowska polityka narodowościowa ZSRR}

Momentem zwrotnym w polityce narodowościowej ZSRR była śmierć Stalina, po którym władzę w Związku przejął Nikita Chruszczow (1894-1971). Nowy lider postanowił dokonać pewnej liberalizacji systemu i skorygował postanowienia części realizowanych dotychczas polityk narodowościowych i tym samym powrócił do sytuacji, w której znajdowały się grupy etniczne w latach 20. Jednocześnie podjął działania, które decentralizowały proces polityczny w państwie. Polityka indygenizacji nieco się uspokoiła, a przedstawiciele społeczności lokalnej zaczęli zajmować coraz wyższe stanowiska w lokalnych komitetach partyjnych oraz kręgach władzy ${ }^{188}$. Wprowadzone zmiany, w tym większa wolność działania społeczności lokalnych, miały przyczynić się do złagodzenia występujących między narodowościami różnic i stworzenia w ich miejsca homo sovieticusa, czyli człowieka radzieckiego ${ }^{189}$. Uważano, że dobrze przemyślana polityka narodowościowa doprowadzi w ostateczności do zatarcia dotychczas eksponowanych różnic narodowych.

Cenzus z 1959 r. zarejestrował rekordową liczbę nierdzennej populacji - $10 \mathrm{mln}$ obywateli, czyli 45\% ówczesnej populacji Azji Centralnej stanowili imigranci, przede wszystkim z Rosji. ${ }^{190}$. Sytuacja uległa diametralnej zmianie w drugiej połowie XX w. za rządów Chruszczowa, kiedy nastąpił wzrost liczby urodzeń rdzennych miesz-

184 Ibidem, s. 155-156.

185 W okresie ZSRR Taszkent wyrósł na centrum religijne i kulturowe świata islamskiego Azji Centralnej.

186 Ro'i Y., Islam in the Soviet Union: From the Second World War to Gorbachev, Columbia University Press, New York 2000, s. 62.

187 Z punktu widzenia konstytucjonalizmu Azja Centralna pozostaje regionem sekularnym; ustawa zasadnicza prawnie reguluje rozdział państwa od religii. Khalid A., Islam after Communism..., s. 114.

188 Fowkes B., Ethnicity and Ethnic Conflict in the Post-Communist World, Parlgrave, New York 2002, s. 77.

189 Soucek S., op. cit., s. 232.

190 Kulchik Y., Fadin A., Sergeev V., Central Asia after the Empire, Pluto Press, London 1996, s. 4. 
kańców regionu oraz powrót przedstawicieli narodów Słowiańskich na terytorium Rosyjskiej SRR ${ }^{191}$. Zaistniały trend był odpowiedzią na rosnące dysproporcje oraz marginalizację ludności słowiańskiej w codziennym życiu. Niegdyś uprzywilejowani w społeczeństwie, obecnie zmagali się z ostrą krytyką rdzennych obywateli. Antypatie były odwzajemniane, albowiem Słowianie równie negatywnie wyrażali się o narodowościach lokalnych. Miało to zatem przeciwny do spodziewanego efekt polityki narodowościowej ZSRR, która pod swoim majestatem miała zjednoczyć radzieckich obywateli ${ }^{192}$.

Powojenna władza sowiecka wykorzystywała służbę wojskową jako jedno z narzędzi w procesie społecznej integracji mniejszości narodowych, nauki języka rosyjskiego, łamania poczucia lojalności narodowej, poddawania żołnierzy indoktrynacji politycznej, by ewentualnie stworzyć „Nowego Obywatela Radzieckiego” ${ }^{193}$. W skład jednostek militarnych wchodzili przedstawiciele wszystkich 120 grup etnicznych zamieszkujących w tamtym czasie ZSRR. Obywatele Azji Centralnej stanowili rdzeń niezmilitaryzowanych oddziałów pomocniczych, np. służby bezpieczeństwa wewnętrznego. Mniejszość centralno-azjatycka była podmiotem prześladowań dyskryminacyjnych ze strony starszych rekrutów ${ }^{194}$.

Lata władzy Leonida Breżniewa charakteryzowały się zwiększoną świadomością przedstawicieli partyjnych stacjonujących w pięciu republikach Azji Centralnej. Dinmukhamed Kunaev z Kazachstanu czy Sharaf Rashidov z Uzbekistanu szybko nauczyli się czerpać maksimum korzyści płynących z Moskwy. Wystarczyło ślubować lojalność Kremlowi, by władza centralna przymykała oko na występujące lokalnie wzmocnione zjawiska indygenizacji ${ }^{195}$. Jednocześnie Breżniew preferencyjnie traktował Uzbekistan, który w jego zamyśle był republiką przodującą w regionie. Przewodniczący KPZR powierzył tej republice rolę lidera Azji Środkowej przede wszystkim ze względu na jej czynniki gospodarcze i demograficzne, bogatą historię i kulturę ${ }^{196}$. W konsekwencji doprowadziło to do poczucia wyższości, historycznego namaszczenia i dominującej pozycji narodu uzbeckiego nad pozostałymi mieszkańcami Azji Centralnej ${ }^{197}$. Sytuacja utrzymywała się do czasu, kiedy w drugiej połowie lat 80. Michaił Gorbaczow zarządził proces reform - pierestrojki (restrukturyzacji) i głasnosti (otwartości). W dążeniu ku restrukturyzacji, demokratyzacji, otwartości i przejrzystości państwowej Gorbaczow nie docenił sił narodowych sentymentów,

191 Lubin N., Implications of Ethnic and Demographic Trends, [w:] W. Fierman [red.], Soviet Central Asia: The Failed Transformation, West View Press Inc., Boulder 1991, s. 37.

192 Wixman R., Ethnic Attitudes and Relations in Modern Uzbek Cities, [w:] W. Fierman [red.], Soviet Central Asia..., s. 163-176.

193 Jones E., Red Army and Society: A Sociology of the Soviet Military, Unwin \& Allen, Boston 1985, s. 45.

194 Lubin N., op. cit., s. 37.

195 Soucek S., op. cit., s. 256-258.

196 Capisani G. R., op. cit., s. 127.

197 Tabyliasheva A., „The Challenge of Regional Cooperation in Central Asia. Preventing Ethnic Conflict in Ferghana Valley", s. 4. 
które ów proces zmian gwałtowanie obudzi19198. Od tego też czasu słabym gospodarczo i politycznie zdezorganizowanym Związkiem Radzieckim wstrząsały napięcia i konflikty etniczne. Sytuację dodatkowo destabilizowały dążenia narodowych jednostek administracyjnych do większej autonomii ${ }^{199}$.

Jedną z niespodziewanych konsekwencji polityki pierestrojki i głasnosti były wybuchy konfliktów etnicznych, które ogarnęły ZSRR tuż pod koniec lat 80. Tego rodzaju napięcia międzyetniczne odzwierciedlały sumę - korespondujących ze sobą - indywidualnych postaw i decyzji społecznych. Borys Jelcyn, zachęcając obywateli ZSRR do postaw nacjonalistycznych, których mobilizacja miała odebrać władzę Partii Komunistycznej, w konsekwencji doprowadził do rozpadu ZSRR. W długoterminowej perspektywie rozwój społeczno-gospodarczy oraz restrukturyzacja i modernizacja państwa nie rozwiązały występujących w przestrzeni radzieckiej problemów narodowych, jedynie je wzmocniły.

\section{Podsumowanie}

Blisko 70 lat dziedzictwa radzieckiej polityki narodowościowej ukształtowało poglądy, wierzenia i tożsamości członków narodowości etnicznych Azji Centralnej. Doświadczenia historyczne z okresów kolonialnego i radzieckiego pozostawiły znaczące rysy na wewnętrznym rozwoju republik Azji Centralnej, a spuścizna radzieckich rządów okazała się wielką przeszkodą w procesie wprowadzania w regionie władzy demokratycznej ${ }^{200}$. Lenin i Stalin delimitowali narodowe granice, wyszkolili narodowe elity ${ }^{201}$ oraz rozwinęli narodowe języki i kulturę. Rozpoczęli ten proces, mając w zamyśle cel stworzenia wielkiego Imperium, którego terytorium zachowa swoją jedność dzięki kontrolowanym centralnie, ale rodzącym się lokalnie nacjonalizmom. Narzucając republikom politykę narodowościową, bolszewicy wierzyli w prawo do samostanowienia zarówno w sensie ideologicznym, jak też praktycznym. Uważali, że przeplatając nacjonalizm z radziecką ideologią, zdołają utrzymać cały radziecki naród pod kontrolą. Kurczowo trzymali się nierealistycznego przekonania, że istniejący ówcześnie system etniczny z jedną dominującą w państwie grupą zezwoli na sprawiedliwy podział władzy. Jednak brak zrozumienia dla wieloetniczności, wyolbrzymienie znaczenia nacjonalizmu etnicznego wyłączało z większości proce-

198 Knippenberg H., The Nationalities Question in the Soviet Union, [w:] H. Van Amersfoort, H. Knippenberg [red.], States and Nations: The Rebirth of the Nationalities Question in Europe, Royal Dutch Geographic Association (KNAG) and the University of Amsterdam, Amsterdam 1991, s. 43.

199 Strayer R., Why did the Soviet Union Collapse? Understanding Historical Change, M. E. Sharpe, New York 1998, s. 116.

200 John Stuart Mill, jeden z twórców liberalizmu, w pesymistycznym tonie wyraził się o szansach demokracji w wieloetnicznych państwach, twierdząc, iż w takich krajach stanowi ona tylko przeszkodę. Mill J. S., Considerations on Representative Government (1861), Oxford University Press, Oxford 1974, s. 389-390.

201 W celu zmuszenia rdzennej ludności do porzucenia własnej tożsamości rodowo-plemiennej wykorzystywano m.in. kolektywizację. Modernizacja $\mathrm{w}$ formie konfiskaty bydła i ziemi w warunkach terroru doprowadziła do emigracji ludności. Zmiana systemu gospodarowania z tradycyjnego na socjalistyczny doprowadziła do nierównych szans w budowie systemu społecznego i elit politycznych. 
sów państwowych mniejszości etniczne, które nie czuły się związane ani z danym społeczeństwem, ani z konkretnym państwem. Rażącym zaniedbaniem stało się ignorowanie ludów koczowniczych od wieków zamieszkujących i przemierzających bezdroża regionu i w bezpośrednim stopniu wpływających na wieloetniczny charakter obszaru. Zróżnicowana struktura socjopolityczna ludów Azji Centralnej połączonych ze sobą więzami pokrewieństwa oraz relacjami ekonomicznymi nie sprzyjała krystalizacji silnej tożsamości narodowej. Przeszkodą pozostaje mniejszość rosyjska, którą Moskwa wykorzystuje do manipulowania nową władzą republik, nie chcąc stracić w nich obszaru wpływów.

Islam nieprzerwanie kształtuje przestrzeń społeczno-polityczną, wartości i stosunki między ludźmi. Jednak wykorzystywany jako narzędzie w walce o wpływy polityczne i władzę nadal intensyfikuje napięte już relacje zarówno w skali państwa, jak też regionu. Niepodległe republiki napotykały wiele problemów w procesie kreowania społeczeństwa, które z państwem powinna łączyć więź przynależności.

Polityka narodowościowa ZSRR stworzyła dobre warunki do rozwoju upolitycznionego poczucia przynależności do ziemi ojczystej. Suny wielokrotnie podkreślał znaczenie roli radzieckiej władzy w kreowaniu narodowości etnicznych osiadłych na określonym terytorium $\mathrm{z}$ formalnie wyodrębnionymi instytucjami władzy. Twierdził również, iż mimo wszystko to właśnie dzięki władzy radzieckiej powstały podwaliny państwowości w zrzeszonych republikach ${ }^{202}$, z czym należy się zgodzić. Okres władzy sowieckiej to czas, kiedy procesy narodowościowe nabierały siły i znaczenia; czas, kiedy narodowości stawały się zgraną społecznością, którą charakteryzowało poczucie przynależności terytorialnej, tożsamości narodowej, członków której łączył wspólny, narodowy interes. Niemniej jednak implementowane w Azji Centralnej strategie narodowe nigdy nie stanowiły spójnej i homogenicznej polityki, która mogłaby przynosić realne efekty w skali Związku i danego narodu. Kreowanie granic, wykorzystywanie cenzusu jako narzędzia politycznego, promocja języków narodowych, a przede wszystkim polityka natywizacji wymierzone w stworzenie narodowych kadr lokalnych urzędników były traktowane jako instrumenty władzy radzieckiej promujące przynależność narodową. W całym tym procesie zapomniano, iż Rosja nie była państwem narodowym zamieszkiwanym jedynie przez etnicznych Rosjan. Tak samo republiki Azji Środkowej nie pozostawały wyłączną własnością jednej grupy tytularnej. Kazachstan nadal jest państwem tak samo tureckim, jak i rosyjskim. Tadżykistan jest perski i turecki; Uzbekistan - turecki i perski. W rzeczywistości wszystkie państwa Azji Centralnej są wieloetniczne, ukształtowane z wielonarodowego społeczeństwa, które uległo rozpadowi po tym, jak zdewaluowano jego ideologię $e^{203}$. W pierwszej fazie struktura federalna pomogła przybrać narodom konkretny kształt, rozmiar i granice ich ojczyzn. W drugiej, korienizacja preferencyjnie traktująca ludność tytularną w ich

202 Suny R. G., op. cit., s. 192.

203 Brill Olcott M., Nation Building and Ethnicity in the Foreign Policies of the New Central Asian States, s. 214. 
republikach przyczyniła się do wzrostu nierówności między grupami etnicznymi i postępującej równolegle dyskryminacji ${ }^{204}$.

Władza starała się jednoczyć siły w kontroli nad lokalnymi grupami etnicznymi, tym samym minimalizując możliwości politycznej mobilizacji wśród przedstawicieli rdzennych narodowości. W pewnym stopniu sytuacja etniczna w ZSRR zależała zarówno od polityki Moskwy, jak też sytuacji wewnętrznej w każdej z republik. Nie udało się Związkowi Radzieckiemu zasymilować ze sobą wszystkich grup etnicznych, a radziecka polityka narodowościowa i etnofederalizm przyczyniły się tylko do zaognienia rywalizacji między różnymi nacjami.

Związek Socjalistycznych Republik Radzieckich był w rzeczywistości związkiem różnych podmiotów administracyjnych stworzonych na potrzeby realizacji polityki narodowej Moskwy, funkcjonujących na zasadach parapaństwowych. Radziecki socjalizm przeplatał się tam $\mathrm{z}$ nacjonalizmem. Radziecka gospodarka planowa dążyła ku samowystarczalności, a polityka nacjonalistyczna uzupełniała plany i ambicje radzieckiej władzy. Można zaryzykować stwierdzenie, iż kategorie narodowe wykreowane przez radziecką politykę narodowościową i przypisane ludom Azji Centralnej poddawano reifikacji i neutralizacji przez cały XX wiek. Wskazuje na to brak ciągłości w kategoriach tożsamości narodowej populacji Azji Centralnej, która zamieszkiwała terytorium środkowoazjatyckie przed 1920 r., a pięcioma narodowościami, które wyłoniły się w dobie niepodległości. Neil Melvin w Russians Beyond Russia: The Politics of National Identity podkreślił, iż niezależna Azja Centralna to nic więcej, jak tylko wyraźny podzbiór post-sowieckich państw charakteryzujących się kwasi-dynastycznym autorytarianizmem oraz tendencją do posługiwania się nieformalnymi zasadami działania i wykorzystywania patrymonialnych porozumień ${ }^{205}$.

Związek Socjalistycznych Republik Radzieckich upadł w 1990 r., ale jego problemy nie przestały istnieć nawet $\mathrm{w}$ drugiej dekadzie XX wieku. Moskwa, poszukująca niestrudzenie historycznych i kulturowych przesłanek, które uprawniłyby ją do wysuwania jeszcze większych roszczeń wobec republik środkowoazjatyckich, gdzieś na tej drodze zagubiła się w swoich imperialistycznych zapędach i tym samym pozwoliła innym odebrać kawałek swojej strefy wpływów. Próbując zrekompensować sobie straty z początków suwerenności republik, obecna Rosja daje jasny sygnał światu, że chce wrócić do carskich granic. Ale czy w tych dążeniach sięgnie również po Azję Centralną?

204 Stalin uważał, że nowo powstałe narodowości należą do kategorii socjalistycznych, czyli narodów w większym stopniu zjednoczonych oraz z większą szansą przetrwania niż jakakolwiek społeczność mieszczańska; narodów, które staną się podstawą późniejszej radzieckiej polityki narodowościowej. Polityka narodowościowa ZSRR oparta była na dwóch odmiennych koncepcjach. Do połowy lat 30. XX w. dominował konstruktywizm. Po niej w polityce narodowościowej zaczęło dominować pojęcie etniczności jako zjawiska primordialnego („pierwotnego”).

205 Za: Hughes J., Sasse G., Comparing Regional and Ethnic Conflicts in Post-Soviet Transition States, „Regional \& Federal Studies”, Vol. 11, Issue 3, 2001, s. 29. 


\section{Pre-soviet national identity in Central Asia in the context of the Soviet Union's natonalities policy; research review}

The nearly 70 years of operation of the Soviet nationalities policy in Central Asia have shaped the views, beliefs and identities of the members of the local ethnic groups. The historical experience from the colonial and Communist periods have left significant scratches on the internal development of the Central Asian republics, while the legacy of the Soviet rule proved to be a great obstacle in the democratisation of the region.

At the time of the imposition of nationality policy, the Bolsheviks believed in the right to self-determination, both in the ideological and practical meaning. They assumed that intertwining nationalism with the Soviet ideology would allow them to keep the whole Soviet nation under control. They clung to the unrealistic belief that their ethnic system based on one dominant group in each state would translate into an equitable distribution of power. However, the lack of understanding for multi-ethnicity, as well as the exaggeration of the importance of ethnic nationalism would exclude ethnic minorities from most national processes, as they would feel no connection with the society or the state. One instance of gross negligence was the disregard of the nomadic peoples inhabiting and traversing the wilderness of the region for centuries, thus directly affecting the multi-ethnic character of the area. The diverse socio-political structures of the peoples of Central Asia connected both by kinship and economic relations were not conducive to the crystallisation of a strong national identity. The Russian minority constitutes another obstacle, as it is used by Moscow to manipulate the new authorities of the republics in order to keep its area of influence.

Islam remains a major force, shaping the socio-political space, values and social relations. However, when used as a tool in the fight for political influence and power, it continues to intensify the already strained relations both at national and regional level. The independent republics encountered many obstacles in the improvement of social conscience among their residents, who should be bound with their state by their sense of belonging.

The Soviet nationalities policy established favourable conditions for the development of a politicised sense of belonging to the homeland. The period of Soviet rule is the time of a rise in strength and importance of ethnic processes, a time when various ethnicities blended into harmonious society, characterised by a sense of territorial belonging and national identity, the members of which were bound by a common, national interest. However, the national strategies implemented in Central Asia never formed a coherent and homogeneous policy that could bring real results on the scale of the Soviet Union or a given state. The establishment of borders, the use of the census as a political tool, the promotion of national languages and, above all, the nationalisation policies aimed at founding the administrative structures on local officials, were all treated as instruments of Soviet authority serving to promote the sense of national belonging.

However, this process was implemented with no regard for the fact that Russia was not a nation-state inhabited solely by ethnic Russians. The Central Asian republics were not an exclusive property of one titular group. Kazakhstan is still both Turkish and Russian by culture. Tajikistan is Persian and Turkish; Uzbekistan is Turkish and Persian. In fact, all Central Asian states are multi-ethnic, originating from a multi-national society, which disintegrated due to the devaluation of its ideology.

The Soviet Union collapsed, but its issues persist. The authorities in Moscow, tirelessly seeking historical and cultural grounds to legitimise ever-larger claims against the Central Asian republics, somehow lost grip of their imperialist ambitions, thus allowing others to take over a part of their sphere of influence. In an attempt to compensate for the losses from the initial period of sovereignty of the new states, modern-day Russia gives a clear signal to the world that it intends to reinstate the borders of tsarist Russia. Will this assertion also affect Central Asia? 


\section{Досоветская национальная идентичность в Средней Азии в контексте национальной политики СССР. Обзор исследований.}

Почти 70 лет наследия советской национальной политики сформировало взгляды, верования и идентичности членов этнических народов Средней Азии. Исторический опыт колониального и советского периодов оставили заметные трещины на внутреннем развитии среднеазиатских республик, а наследие советского правления оказалось большим препятствием в процессе введения в регионе демократической власти.

Навязывая республикам национальную политику, большевики верили в право к самоопределению как в идеологическом, так и в практическом смысле. Они считали, что переплетая национализм с советской идеологией, они сумеют удержать весь советский народ под контролем. Они судорожно придерживались нереалистичного убеждения, что существующая тогда этническая система с одной, доминирующей в государстве, группой позволит справедливо распределить власть. Однако непонимание многоэтничности, преувеличение значения этнического национализма исключало из большинства государственных процессов этнические меньшинства, которые не чувствовали себя связанными ни с данным обществом ни с конкретным государством. Вопиющим упущением стало игнорирование кочевнических народов, с незапамятных времен живущих и путешествующих по бездорожьям региона и, в непосредственной степени, влияющих на многоэтнический характер территории. Неоднородная социо-политическая структура среднеазиатских народов, соединенных друг с другом кровными узами, а также экономическими связями, не способствовали кристаллизации сильной национальной идентичности. Препятствием остается русское меньшинство, используемое Москвой, не желающей потерять в них сферы влияния, в манипулировании новыми властями республик.

Ислам непрерывно формирует общественно-политическое пространство, ценности и человеческие отношения. Однако им пользуются как орудием в борьбе за политическое влияние и власть, что продолжает интенсифицировать итак уже натянутые отношения как в государственном, так и региональном масштабе. Независимые республики встретились с многими проблемами в процессе создания общества, которое должно быть соединено с государством узами принадлежности.

Национальная политика СССР создала хорошие условия для развития политизированного чувства принадлежности к родной земле. Период советской власти - это время, когда национальные процессы приобретали силу и значение. Время, когда нации превращались в сплоченное общество, характеризующееся чувством территориальной принадлежности, национальной идентичности, членов которого соединял общий, национальный интерес. Тем не менее, однако, имплементированные в Средней Азии национальные стратегии никогда не представляли собой стройной и гомогенной политики, которая могла бы приносить реальные результаты в масштабе Союза и данной нации. Создание границ, использование ценза, как политического орудия, продвижение национальных языков, а прежде всего политика нативизации, направленная на создание национальных кадров из местных чиновников трактировались как инструменты советской власти, продвигавшие национальную принадлежность.

Во всем этом процессе было забыто, что Россия не была национальным государством, заселенным исключительно этническими русскими. Среднеазиатские республики не оставались исключительной собственностью одной номинальной группы. Казахстан по-прежнему остается государством в равной мере как турецким так и русским. Таджикистан - персидским и турецким; Узбекистан - турецким и персидским. В действительности, все государства Средней Азии - многоэтничны, сформированы из многонационального общества, которое подверглось распаду после того, как его идеология была девальвирована. 
Совет Социалистических Советских Республик распался, но его проблемы не прекратили своего существования. Москва, в неутомимых поисках исторических и культурных предпосылок, которые узаконили бы ее претензии на более большие притязания по отношению к среднеазиатским республикам, где-то на этом пути запуталась в своих империалистических поползновениях и тем самым позволила другим отнять кусок своей зоны влияния. Пытаясь компенсировать свои убытки, возникшие в начале суверенитета республик, нынешняя Россия дает миру ясный сигнал, что она хочет вернуться к границам царской империи. Но будет ли в этих стремлениях также домогаться Средней Азии?

Перевод Агнешка Поспишыль

\section{Bibliografia}

Aasland A., Russians outside Russia: the New Russian Diaspora, [w:] G. Smith [red.], The Nationalities Question in the Post - Soviet States, Longman, London and New York 1996.

Abazov R., Culture and Customs of the Central Asian Republics, Greenwood 2007.

Abdullayev A., Islamic Tradition of Raising Children and its Applicability in Uzbekistan, „Muslims of Soviet East", 1980/1.

Allworth E., The 'Nationality' Idea in Czarist Central Asia, [w:] E. Goldhagen [red.], Ethnic Minorities in the Soviet Union, Praeger, New York 1968.

Appleby I., Uninvited guests in the communal apartment: nation formation processes among unrecognized Soviet nationalities, „Nationalities Papers”, Vol. 38, No. 6, 2010.

Babakhan Z., Islam and Muslims in the Land of Soviets, tr. R. Dixon, Progress Publishers, Moscow 1980.

Batalden S. K., Batalden S. L., The Newly Independent States of Eurasia: Handbook of Former Soviet Republics, The Oryx Press, Phoenix 1997.

Bennigsen A., Islam and Political Power in the USSR, [w:] G. Benavides, M. W. Daly [red.], Religion and Political Power, SUNY, Albany 1989.

Bennigsen A., Lemercier-Quelquejay Ch., 'Official' Islam in the Soviet Union, „Religion in Communist Lands", Vol. 7, Issue 3, Keston College, Keston 1979.

Benningsen A., Wimbush S. E., Muslims of the Soviet Empire, C. Hurst \& Company, London 1985.

Bergne P., The birth of Tajikistan: national identity and the origins of the Republic. Volume 1 of International Library of Central Asia Studies. I. B. Tauris, London 2007.

Blank S., Soviet Reconquest of Central Asia, [w:] H. Malik [red.], Central Asia: Its Strategic Important and Future Prospects, St. Martin's Press, New York 1994.

Bodio T., Załęski P., Elity władzy w Azji Centralnej. Transformacja - Modernizacja - Etnopolityka, Dom Wydawniczy ELIPSA, Warszawa 2008.

Bohr A., Crisp S., Kyrgyzstan and the Kyrgyz, [w:] G. Smith [red.], The Nationalities Question in the Post - Soviet States, Longman, London \& New York 1996.

Bohr A., Turkmenistan and the Turkmen, [w:] G. Smith [red.], Nationalities Question in the Post-Soviet States, Longman, London 1998.

Bremmer I., Post-Soviet Nationalities Theory: Past, Present, and Future, [w:] I. Bremmer, R. Taras [red.], New States, New Politics: Building the Post-Soviet Nations, Cambridge University Press, Cambridge 1997.

Bremmer I., Reassessing Soviet Nationalities Theory, [w:] I. Bremmer, R. Taras [red.], Nations and Politics in the Soviet Successor States, Cambridge University Press, Cambridge 1993.

Breuilly J., Nationalism and the State, Manchester University Press, Manchester 1982.

Brill Olcott M., Central Asia’s Post-Empire Politics, „Orbis”, Vol. 36, No. 2, Spring 1992. 
Brill Olcott M., Kazakhstan: Pushing for Eurasia, [w:] R. Taras [red.], New States, New Politics: Building the Post - Soviet Nations, Cambridge University Press, Cambridge 1997.

Brill Olcott M., Nation Building and Ethnicity in the Foreign Policies of the New Central Asian

States, [w:] R. Szporluk [red.], National Identity and Ethnicity in Russia and the New States of Eurasia, „The International Politics of Eurasia”, Vol. 2, M. E. Sharpe, New York 1994.

Brill Olcott M., The Kazakhs, Hoover Institution Press, Stanford 1987.

Brubaker R., Nationhood and the National Question in the Soviet Union and Post - Soviet Eurasia: An Institutionalist Account, „Theory and Society”, Vol. 23, No. 1, 1994.

Capisani G. R., Nowe Państwa Azji Środkowej, Dom Wydawniczy ELIPSA, Warszawa 2008.

Chokaiev M., Turkestan and the Soviet Regime, „Journal of the Royal Central Asian Society”, 18 (1931).

Collier P., The Political Economy of Ethnicity, [w:] Annual World Bank Conference on Development Economics 1998, [red.] Pleskovic B., Stiglitz J. E., The World Bank, Washington, D.C. 1999.

Coppieters R., Form and Content in Soviet and Post-Soviet Nationality and Regional Policies, [w:] M. Waller, B. Coppieters, A. Malashenko [red.], Conflicting Loyalties and the State in Post-Soviet Russia and Eurasia, Frank Cass Publishers, London 1998.

Czuma I., Konstytucja Rosji Sowieckiej, Krakowska Spółka Wydawnicza, Kraków 1923.

D'Encausse H. C., Organizing and Colonizing the Conquered Territories, [w:] E. Allworth [red.], Soviet Nationality Problems, New York: Columbia 1971.

Dahl R., Polyarchy: Participation and Opposition, Yale University Press, New Haven 1971.

Denison M., Identity Politics in Central Asia, „Asian Affairs”, 34 (1): 58, 2003.

Diener A., Homeland as Social Construct: Teritorialization among Kazakhstan's Germans and Koreans, „Nationalities Papers”, Vol. 34, No. 2, 2006.

Dienes L., Pasturalism in Turkestan: Its Decline and Its Persistence, „Soviet Studies”, Vol. 27, 1975. Edgar A. L., The Making of Soviet Turkmenistan, Princeton University Press, Princeton 2004.

Edwards M., A Broken Empire: Kazakhstan, „National Geographic Magazine”, 183, No. 3, March 1993.

Ekiert M., Islam w Azji Środkowej, „Za Uralem”, nr 4/1996.

Encyclopedia Britannica, http://www.britannica.com/EBchecked/topic/316850/Khorasan stan z dnia 23-06-2014.

Erşahin S., The Official Interpretation of Islam under the Soviet Regime under the Soviet regime A base for understanding of contemporary Central Asian Islam, „Journal of Religious Culture”, No. 77, Frankfurt am Main Johann-Wolfgang-Goethe-University, 2005.

Fabri M., Demographic Processes, Nationalism and Ethnic Conflicts, [w:] A.G. Vishnevskyay [red.] Encyclopedia of Life Support Systems, Population and Development: Challenges and Opportunities, Vol. 1, 2009.

Falkowski M., Charakterystyka regionu Azji Centralnej, [w:] B. Bojarczyk, A. Ziętek [red.] Region Azji Centralnej jako obszar wpływów międzynarodowych, Wydawnictwo Uniwersytetu Marii Curie- Skłodowskiej, Lublin 2008.

Fedorenko V., Central Asia: From Ethnic to Civic Nationalism, „Rethink Paper”, March 2012.

Fierman W., Identity, Symbolism and the Politics of Language in Central Asia, „Europe - Asia Studies", Vol. 61, No. 7, 2009.

Fowkes B., Ethnicity and Ethnic Conflict in the Post-Communist World, Parlgrave, New York 2002. Gellner E., Nationalism, Weidenfeld \& Nicholson, Londyn 1997.

Gellner E., Nations and Nationalism, Cornell University Press, Ithaca, New York 1983.

Gleason G., Uzbekistan: The Politics of National independence, [w:] I. Bremmer, R. Taras [red.], Soviet States, New Politics: Building the Post-Soviet Nations, Cambridge University Press, Cambridge 1997.

Haugen A., The Establishment of National Republics in Soviet Central Asia, New Hampshire: Palgrave MacMillan, 2003. 
Hirsch F., The Soviet Union as a Work-In-Progress: Ethnographers and the Category Nationality in the 1926, 1937 and 1939 Censuses, „Slavic Review”, Vol. 56, No. 2, 1997.

Hirsch F., Empire of Nations: Ethnographic Knowledge and the Making of the Soviet Union, Cornell University Press, New York 2005.

Hobsbawm E., Nations and Nationalism Since 1780: Programme, Myth and Reality, Cambridge University Press, Cambridge 1990, s. 168.

Hopkirk P., The Great Game: The Struggle for Empire in Central Asia, New York; Tokyo \& London: Kodansha International 1994.

Hotamov I., We Faded Away in Bukhara, [w:] M. Shakurzoda [red.], Tajiks, Arians and the Iranian Plateau, Teheran 2001.

Hughes J., Sasse G., Comparing Regional and Ethnic Conflicts in Post-Soviet Transition States, „Regional \& Federal Studies”, Vol. 11, Issue 3, 2001.

Imomov A., Territorial and Water Conflicts in Central Asia: A View from Tajikistan, „Central Asia and Caucasus", Vol. 14, Issue 2, 2013.

Jones E., Red Army and Society: A Sociology of the Soviet Military, Unwin \& Allen, Boston 1985.

Jourek O. N., Ethno - political Conflicts in Post - Communist Societies: Prospects for Resolution and Prevention in the Context of International Law, Harvard University, John F. Kennedy School of Government, Cambridge 1999.

Kemp W., Nationalism and Communism in Eastern Europe and the Soviet Union: A basic contradiction?, Macmillan, London 1999.

Khalid A., Islam after Communism: Religion and Politics in Central Asia, University of California Press, Berkeley 2007.

Khalid A., The Politics of Muslim Cultural Reform: Jadidism in Central Asia, University of California Press, Berkeley 1998.

Kim G., Koreans in Kazakhstan, Uzbekistan and Russia, World Diasporas Encyclopedia, Vol. 2, Kluwer 2004.

Klüter H., People of German Descent in CIS States - Areas of Settlement, Territorial Autonomy and Emigration, „GeoJournal”, Vol. 31, No. 4, 1993.

Klyashtorny S. G., Sultanov T. I., Kazakhstan: Annals of Three Millennia, Almaty 1992.

Knippenberg H., The Nationalities Question in the Soviet Union, [w:] H. Van Amersfoort, H. Knippenberg [red.], States and Nations: The Rebirth of the Nationalities Question in Europe, Royal Dutch Geographic Association (KNAG) and the University of Amsterdam, Amsterdam 1991.

Kolossov V., Nationalism versus "World Society": A view from Russia, [w:] P. J. Taylor [red.], Political Geography of the Twentieth Century: A Global Analysis, John Wiley \& Sons, Chichester \& New York 1995.

Kolstoe P., Russians in the Former Soviet Republics, Hurst, London 1995.

Konstytucja Związku Socjalistycznych Republik Radzieckich z 1924 r., tłum. S.R. Dobrowolski, Warszawa 1977.

Konstytucja ZSRR z 1936 r., Bucknell University, strona internetowa http://www.departments. bucknell.edu/russian/const/1936toc.html stan z dnia 23-06-2014.

Konstytucja ZSRR z 1936 r. strona internetowa https://constitutii.files.wordpress.com/2013/01/ 1936-en.pdf.

Kowalski J., Konstytucja Federacji Rosyjskiej a Rosyjska i Europejska tradycja konstytucyjna, Iuris Polskie Wydawnictwo Prawnicze Sp. z o.o., Warszawa-Poznań 2009.

Kulchik Y., Fadin A., Sergeev V., Central Asia after the Empire, Pluto Press, London 1996.

Landowski Z., Islam. Nurty, odłamy, sekty, Książka i Wiedza, Warszawa 2008.

Lenin W., Powne zibrannia tworiw, t. 35, Kyjiw 1981.

Lewis M. L., Ethnic Strife and the Reinvention of Uzbek Identity, GeoCurrents.info, strona internetowa http://geocurrents.info/geopolitics/ethnic-strife-and-the-reinvention-of-uzbek-identity stan $\mathrm{z}$ dnia 23-06-2014. 
Lityński A., Prawo Rosji i ZSRR 1917-1991, czyli historia wszechzwiązkowego komunistycznego prawa (bolszewików). Krótki kurs, Wydawnictwo C.H. Beck, Warszawa 2010.

Lubin N., Implications of Ethnic and Demographic Trends, [w:] W. Fierman [red.], Soviet Central Asia: The Failed Transformation, West View Press Inc., Boulder 1991.

Lustick I., Stability in Deeply Divided Societies, „World Politics”, Vol. 31, No. 3, 1979.

Madih A. A., The Kurds of Khorasan, „Iran and the Caucasus”, Vol. 11, No. 1, 2007.

Martin T., The Affirmative Action Empire: Nations and Nationalism in the Post-Soviet Union, 1923-1939, Cornell University Press, Ithaca 2001.

Martin T., An Affirmative Action Empire: The Soviet Union as the Highest Form of Imperialism, [w:] R. G. Suny, T. Martin [red.], A State of Nations: Empire and Nation-Making in the Age of Lenin and Stalin, New York 2001.

Mill J. S., Considerations on Representative Government (1861), Oxford University Press, Oxford 1974.

Nairn T., Faces of Nationalism: Janus Revisited, Verso, New York 1997.

NationMaster, strona internetowa http://maps.nationmaster.com/country/sr/1 stan $\mathrm{z}$ dnia 23-06-2014.

O'Leary B., Nationalism and Ethnicity: Research Agendas on Theories of Their Sources and Their Regulation, [w:] D. Chirot, M.E.P. Saligman [red.], Ethnopolitical Warfare: Causes, Consequences and Possible Solutions, American Psychological Association, Washington 2001.

Olson J. S. [red.], An Ethnohistorical Dictionary of the Russian and Soviet Empires, L.B. Pappas \& N.C.J. Pappas, CT: Greenwood Press, Westport 1994.

Pavlenko A., Multilingualism in Post - Soviet Countries: Language Revival, Language Removal, and Sociolinguistic Theory, „The International Journal of Bilingual Education and Bilingualism”, Vol. 11, No. 3-4, 2008.

Pipes R., The Formation of the Soviet Union: Communism and Nationalism 1917-1923, Massachusetts: Harvard Cambridge 1970.

Rashid A., Dżihad. Narodziny wojującego islamu w Azji Środkowej, Wydawnictwo Akademickie Dialog, Warszawa 2003.

Rezvani B., „East Asian Ethnic Groups in Central Asia, Culture and Human Being”, Vol. 4, No. 2, 2008.

Rezvani B., Ethno-territorial conflict and coexistence in the Caucasus, Central Asia and Fereydan, Amsterdam University Press, 2013.

Ro'i Y., Islam in the Soviet Union: From the Second World War to Gorbachev, Columbia University Press, New York 2000.

Rohoziński J., Bawełna, Samowary i Sartowie. Muzułmańskie Okrainy Carskiej Rosji 1795-1916, Wydawnictwo Akademickie Dialog, Warszawa 2014.

Roy O., Islam in Tajikistan, „Occasional Paper”, No. 1, New York: The Project on Open Society in Central Eurasia, July 1996.

Roy O., The New Central Asia. The Creation of Nations, Londyn-Nowy Jork 2000.

Rumer B. Z., Soviet Central Asia: A Tragic Experiment, London 1989.

Sagdeev R., Central Asia and Islam: An Overview, [w:] R. Sagdeev, S. Eisenhower [red.], Islam and Central Asia: An Enduring Legacy or an Evolving Threat?, Center for Political and Strategic Studies, Washington, D.C. 2000.

Sagdullaev A. S., Starożytne korzenie państwa Uzbeków, [w:] T. Bodio [red.], Uzbekistan: historia, społeczeństwo, polityka, Wydawnictwo Elipsa, Warszawa 2001.

Schafer D. E., Local Politics and the Birth of the Republic of Bashkortostan, 1919-1920, [w:] R. G. Suny, T. Martin [red.], A State of Nations: Empire and Nation-Making in the Age of Lenin and Stalin, New York 2001.

Segars A., Nation Building in Turkey and Uzbekistan, [w:] T. Evereath-Heath [red.], Central Asia, Aspects of Transition, London New York, Routledge Curzon 2003. 
Sengupta A., Frontiers into borders the transformation of identities in Central Asia, Hope India Publications, Greenwich Milennium, London 2002.

Sengupta, A., The formation of the Uzbek nation-state: A study in transition, Lanham, MD: Lexington Books, 2003.

Shaw C., Friendship under Lock and Key: the Soviet Central Asian Border, 1918-1934, „Central Asia Survey", Vol. 30, No. 3-4, 2011.

Shiokawa N., The History of Soviet Language Policy Reconsidered, „Slavic Studies”, Vol. 46, 1999.

Slezkine Y., The USSR as a Communal Apartment, or How a Socialist State Promoted Ethnic Particularism, „Slavic Review”, Vol. 53, No. 2, 1994.

Smith G., Nationalities Policy, [w:] G. Smith [red.], The Nationalities Question in the Post-Soviet States, Longman, London 1996.

Smith G., Post-colonialism and Borderland Identities [w:] G. Smith, V. Law, A. Wilson, A. Bohr, E. Allworth [red.], Nation-Building in the Post-Soviet Borderlands: The Politics of National Identities, Cambridge University Press, Cambridge 1998.

Smith J., The Bolsheviks and the National Question, 1917-23, Palgrave Macmillan, London 1999. Soucek S., A History of Inner Asia, Cambridge University Press, Cambridge 2000.

Stalin J. W., Marksizm a kwestia narodowa, [w:] idem, Dzieła, t. 2, Warszawa 1949.

Strayer R., Why did the Soviet Union Collapse? Understanding Historical Change, M. E. Sharpe, New York 1998.

Sultangalieva A., Religion in Transition, „Central Asia Monitor”, No. 6, June 1996.

Suny R. G., Ambiguous Categories: Stats, Empires and Nations, „Post Soviet Affairs”, 11 (2), 1995. Svanberg I., Kazakshtan and the Kazakhs, [w:] G. Smith [red.], The Nationalities Question in the Post - Soviet States, Longman, London and New York 1996.

Szczepanik E., Radzieckie republiki Azji Środkowej 1917-1941: dzieje, gospodarka, społeczeństwo, Zakład Narodowy im. Ossolińskich, Wrocław 1987.

Tabyshalieva A., The Challenge of Regional Cooperation in Central Asia. Preventing Ethnic Conflict in Ferghana Valley, „Peaceworks”, No. 28, United States Institute of Peace 1999.

University of Texas Libraries, http://www.lib.utexas.edu/maps/commonwealth/soviet_union_ mus_pop_1979.jpg stan $\mathrm{z}$ dnia 23-06-2014.

Uyama T., Rethinking the ethnic history of the Kazakhs: Some reflections on historical writing, „Chiiki Kenkyu Ronshu” [JCAS Review], Vol. 2, No. 1, 1999.

Wierzbicki A., Etnopolityka w Azji Centralnej, Dom Wydawniczy Elipsa, Warszawa 2008.

Wixman R., Ethnic Attitudes and Relations in Modern Uzbek Cities, [w:] W. Fierman [red.], Soviet Central Asia: The Failed Transformation, West View Press Inc., Boulder 1991.

Wixman R., The Peoples of the USSR: An Ethnographic Handbook, M. E. Sharp, New York \& London 1984.

Wójcik J., Ruch basmaczy w radzieckiej Azji Środkowej 1918-1933, Fundacja Studiów Międzynarodowych, Warszawa 2008.

Youseff N., The Demographics of Ethnicity: Implications for Project Support in Central Asia, Washington, D.C.: World Bank August 1993.

Zanca R., When Democracy Makes for Failing State: Inter-Ethnic Violence in Kyrgyzstan, „The Illinois International Review", Issue 12, Fall 2010.

Załęski P., Kultura polityczna więzi w Azji Centralnej, Oficyna Wydawnicza ASPRA-JR, Warszawa 2011.

Zapaśnik S., „Walczacy Islam” w Azji Centralnej. Problem społecznej genezy zjawiska, Fundacja na rzecz Nauki Polskiej, Wydawnictwo Uniwersytetu Wrocławskiego Sp. z o.o., Wrocław 2006.

Zevelev I., Russia's Future: Nation or Civilization? - Collapse of the Soviet Union and the 'Russian Question', „Russia in Global Affairs”, Vol. 7, No. 4, 2009.

Zevelev I., Russia and Its New Diasporas, Washington D.C.: United States Institute of Peace Press, 2001. 
Zongqi Z., Ethnic and Religious Contradictions and Their Impacts in Central Asia, [w:] Xintian Yu [red.], Cultural Impact on International Relations, The Council For Research in Values and Philosophy, Washington, Cultural Heritage and Contemporary Change Series III, Asia, Volume 20, 2002.

Metropolitan Museum of Art, strona internetowa https://www.metmuseum.org/toah/ht/10/nc/ map_19th.htm stan z dnia 23-06-2014.

NationMaster, strona internetowa http://maps.nationmaster.com/country/sr/1 stan $\mathrm{z}$ dnia 23-06-2014.Metropolitan Musuem of Arts, strona internetowa http://www.metmuseum.org/ toah/ht/10/nc/map_czar.htm stan z dnia 23-06-2014.

University of Texas Libraries, http://www.lib.utexas.edu/maps/commonwealth/soviet_union_ mus_pop_1979.jpg stan z dnia 23-06-2014.

Anna Perkowska - niezależna doktorantka współpracująca z Instytutem Historii i Nauk Politycznych na Uniwersytecie w Białymstoku. Zajmuje się szeroko rozumianą geopolityką regionu Azji Centralnej. Autorka publikacji w tym zakresie. Obecnie pracuje nad dysertacją doktorską dotyczącą zmian społecznych w Azji Centralnej powstałych w wyniku wieloletniego skażenia środowiska. (anna.perkowska@onet.eu) 